Transactions of the Karelian Research Centre of the Russian Academy of Sciences

No. 10. 2021. P. 25-43

DOI: $10.17076 /$ geo1492
Труды Карельского научного центра РАН № 10. 2021. C. 25-43

УДК $55(474.2)+550.4$

\title{
GEOLOGY AND GEOCHEMISTRY OF A PALEOPROTEROZOIC IRON MINERALIZATION IN NORTH-EASTERN ESTONIA
}

\author{
S. Nirgi ${ }^{1,2}$, A. Soesoo ${ }^{2,3}$ \\ ${ }^{1}$ Geological Survey of Estonia, Rakvere, Estonia \\ ${ }^{2}$ Institute of Ecology and Earth Sciences, Department of Geology, University of Tartu, Estonia \\ ${ }^{3}$ Institute of Geology, Tallinn University of Technology, Estonia
}

The Estonian Precambrian basement is considered as a southern continuation of the Fennoscandian Shield of the East European Craton. Magnetite and sulphide mineralization is historically known in the Jõhvi structural zone, North-eastern Estonia. The mineralized beds are subvertical, with complicated internal structural outlines and a large range of rock types. The newly presented data of 1700 structural measurements and 110 geochemical samples are based on the analysis of two new inclined boreholes drilled in 2019-2020. Magnetite occurs as anhedral grains elongated along the rock fabric, as rounded inclusions in other minerals, or as tiny platelets along grain edges and along cleavage planes of amphibole and biotite. Sulphides are present as pyrite, pyrrhotite in addition to minor chalcopyrite, arsenopyrite and iron arsenide - loellingite, galena and sphalerite. Loellingite and arsenopyrite are commonly related to quartz-feldspar veining. Several samples show elevated Au content (up to 205 ppb), which is often observed in magnetite-sulphide mineralized beds, but sometimes in surrounding garnet gneisses as well. The study reveals unusually high manganese contents of $0.2-13.6$ wt\% in a number of mineralized samples and occasionally in the surrounding gneisses. The new drill core data support the understanding that the Jõhvi Zone is geologically similar to Bergslagen in Sweden and possibly to Orijärvi in southern Finland.

Ke yw ords: geochemistry; iron- and sulphide mineralization; Precambrian basement; Jõhvi zone; Estonia.

\section{С. НИРГИ, А. СоэСОО. ГЕОЛОГИЯ И ГЕОХИМИЯ ПАЛЕОПРОТЕРОЗОЙ- СКОГО ЖЕЛЕЗИСТОГО КОМПЛЕКСА СЕВЕРО-ВОСТОЧНОЙ ЭСТОНИИ}

Приводятся новые данные по исследованию геологии фундамента Эстонии, сложенного докембрийскими образованиями в южной части Восточно-Европейского кратона Фенноскандинавского щита. Основу материалов составляют результаты по скважинам бурения 2019-2020 гг. В проведенном анализе использованы данные 1700 структурных измерений и данные по 110 геохимическим пробам. Установлены субвертикальные минерализованные пласты со сложными структурными особенностями и различными типами докембрийских пород. Минералогические особенности выражены в том, что магнетит встречается в виде вытянутых вдоль ткани породы двугранных зерен, округлых включений в других минералах или в виде крошечных пластинок по краям зерен и вдоль плоскостей спайности амфибола и биотита. Отмечено, что оруденение представлено магнетитом и сульфидами. Сульфиды присутствуют в виде пирита, пирротина в дополнение к незначительному содержанию халькопирита, леллингита, галенита и сфалерита. Арсенопирит 
обычно связан с кварц-полевошпатовыми прожилками. Установлено необычно высокое содержание марганца - от 0,2 до 13,6 мас. \%. Новые данные, полученные по керновым пробам из пробуренных скважин, свидетельствуют, что зона Йыхви имеет геологическое сходство с районом Бергслаген в Швеции и, возможно, областью Ориярви в Южной Финляндии.

Ключевые слова: геохимия; железо-сульфидное оруденение; докембрий; фундамент; зона Йыхви; Эстония.

\section{Introduction}

The Estonian Precambrian basement can be considered as a southern continuation of the Svecofennian province of the East European Craton [Bogdanova et al., 2015 and references therein] (Fig. 1, a). This basement comprises two major units: amphibolite facies rocks of northern Estonia, which are similar to the rocks of southern Finland, and mostly granulite facies rocks of southern Esto- nia. Based on geophysical and petrological studies, six structural zones can be distinguished within these major units: the Tallinn, Alutaguse, and Jõhvi zones in northern Estonia, and the West Estonian, Tapa, and South Estonian zones in southern Estonia [Puura et al., 1983; Soesoo et al., 2004, 2006, 2020] (Fig. 1). Since the crystalline rocks are covered by $100-700 \mathrm{~m}$ thick, mostly Paleozoic-age sedimentary rocks, geological information on Proterozoic crystalline rocks in Estonia comes mostly

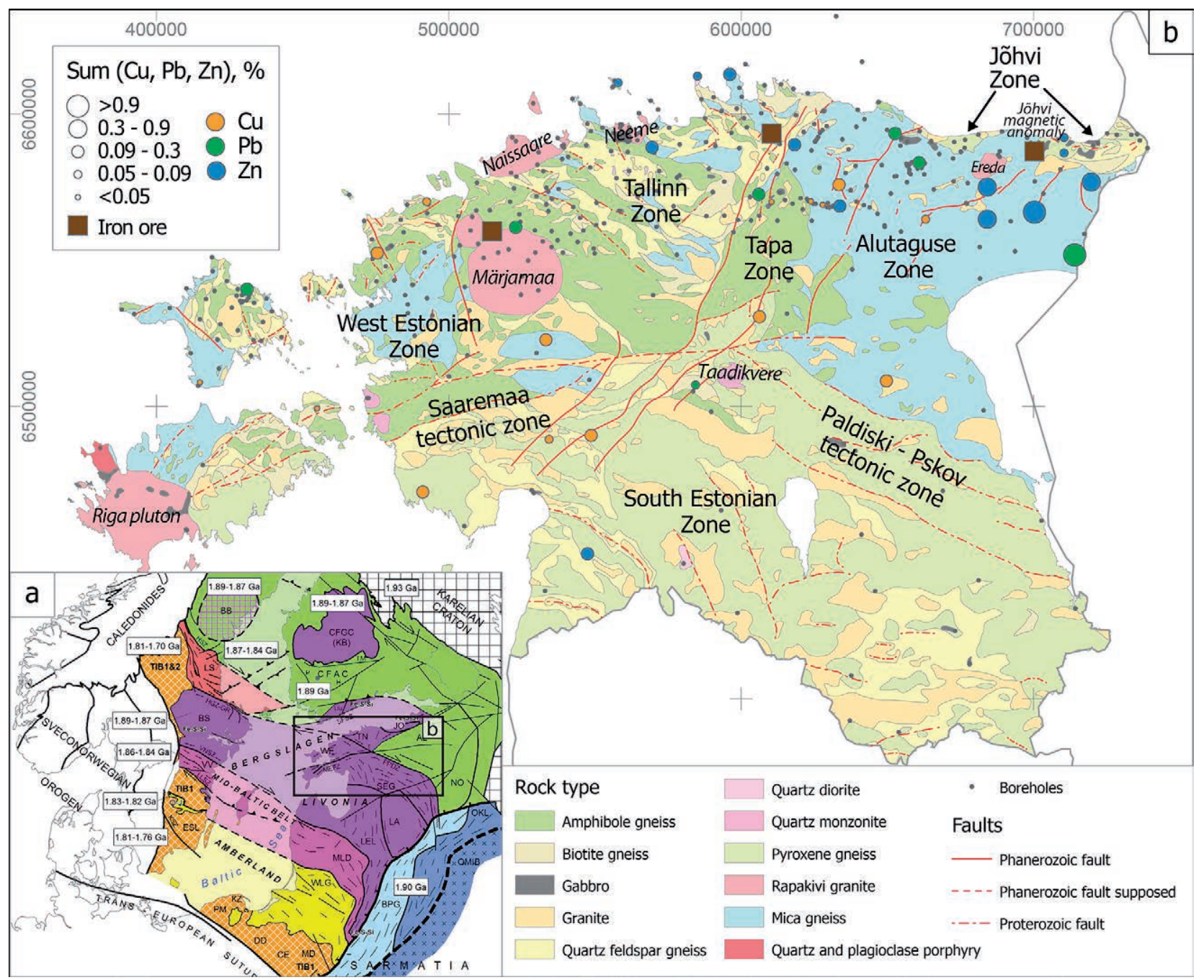

Fig. 1. Estonian crystalline basement in the context of the Svecofennian orogen zones in the neighbouring area (a) and base metal occurrences on the geological map of the Paleo- and Mesoproterozoic crystalline basement of Estonia (b) [Bogdanova et al., 2015] 
from studies of drill core material and geophysical studies. During the 1950s - 1980s, Estonian basement rocks were extensively drilled and mapped and studied for metals. From the metallogenetic point of view, several regions were proposed including the Jõhvi - Uljaste sidero-chalcophilic area in NE Estonia (Fig. 1, b).

Several magnetic anomalies were established from which the most striking was the Jõhvi Magnetic Anomaly, initially discovered already in 1924. The anomaly is situated a few kilometres north of Jõhvi Town in NE Estonia, within the Jõhvi structural zone. The first two boreholes were drilled during 1937-1939 down to depths of 505

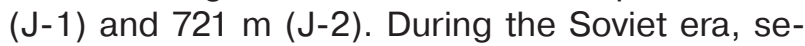
veral exploratory holes were drilled. However, most of the research stopped in the 1980s. None of these drill cores (from 18 drill holes altogether) except $\mathrm{J}-1$ and $\mathrm{J}-2$ have been preserved.

Based on the information which is more than 40 years old, it was established that the Jõhvi magnetite-bearing layers (previously called magnetite quartzites) occur as subvertical beds in garnet-cordierite and pyroxene gneisses. Earlier drillings showed that the complex of ore-bearing gneisses was up to $100 \mathrm{~m}$ thick, and the reserves of iron ore (Fe over $25 \%$ ) were about 355 million tons (calculated to a depth of $500 \mathrm{~m}$ ), or $629 \mathrm{mil}-$ lion tons if calculated to a depth of $700 \mathrm{~m}$ and 1500 million tons if calculated to a depth of $1000 \mathrm{~m}$ [Soesoo et al., 2020, 2021a, b]. These estimates, however, are based on very limited data and need to be verified by detailed drilling in the future. During 2019-2020, two new holes were drilled down to $770 \mathrm{~m}$ into the centre of the western part of the Jõhvi Magnetic Anomaly. These drill cores have now been studied in detail and some of the new results are reported in this article.

\section{Geological settings of the Jõhvi Zone}

The narrow, about 20-30 km wide and $100 \mathrm{~km}$ long Jõhvi Zone in NE Estonia, is separated from the South Estonian Zone by the Alutaguse Zone amphibolite grade gneisses (Fig. 1). The zone is characterized by strong $\mathrm{E}-\mathrm{W}$ trending magnetic anomalies and positive gravity anomalies [Soesoo et al., 2004, 2020]. The Jõhvi Magnetic Anomaly is characterized by the occurrence of extremely strong, up to $19.300 \mathrm{nT}$ E-W trending magnetic anomalies with accompanying slightly positive gravity anomalies [Plado et al., 2020].

The Jõhvi complex mainly consists of pyroxene gneisses and inter-layered quartz-feldspathic gneisses, biotite-plagioclase gneisses, amphibole gneisses, garnet-cordierite gneisses (Vaivara complex), and magnetite-rich gneisses [Jõh- vi Magnetic Anomaly; Puura et al., 1983, 2004; Soesoo et al., 2004, 2006, 2020, 2021a]. Migmatization within the complex is widespread, resulting in the formation of veins and small bodies of rocks with granitic, charnockitic and enderbitic compositions. Generally, these rocks have formed under the conditions of granulite facies metamorphism [Puura et al., 2004; Soesoo et al., 2004, 2006, 2020]. The Jõhvi magnetite-rich layers occur as subvertical beds with complicated structural elements in garnet-cordierite and pyroxene gneisses. Seven historical drill cores out of 18 from the Jõhvi Magnetic Anomaly area contain magnetite-rich layers. Previously, three different magnetic partial anomalies were detected, which were considered as an indication of the occurrence of possible ore mineralization zones (Fig. 2).

Historical drilling and geophysical survey results confirmed the presence of iron ore mineralization at a depth of a few hundred metres in all the partial anomalies, but the size, geometry and continuation of the mineralized zones remained unknown. Puura \& Koppelmaa [1967] assumed that the total thickness of the mineralized section could be between 260-400 m and that at least two $100 \mathrm{~m}$ thick mineralized sections, strata dipping steeply southeast, were separated by aluminiferous gneisses (Fig. 2).

Several hypotheses about the possible deposit type of the mineralization of the Jõhvi Magnetic Anomaly have been proposed. Linari [1940] believed that the magnetite mineralization was similar to skarn deposit types, while Vaganova \& Kadyrova [1948] proposed a metasomatic origin. Tikhomirov [1966] described these rocks as alternating layers of skarn, biotite, and hornfels cut by granite veins. However, the most common is the concept of metamorphism after volcanic sedimentary rock genesis [Puura, Kuuspalu, 1966; Erisalu, Arvisto, 1969]. Based on the magnetite composition, Soesoo et al. [2021a] show that Jõhvi magnetites do not represent clearly any of the common deposit types compared to the results of Dupuis and Beaudoin [2011]. However, it may be that the studied magnetites bear similarities to the skarn type of deposits, albeit having lower nickel and higher manganese concentrations. The analysed magnetites also have a high $\mathrm{Ti}+\mathrm{V}$ concentration, which is not common for typical skarn deposits [Soesoo et al., 2021a]. Therefore, the genesis of the Jõhvi ore complex is still an open question.

Historically, the term "magnetite quartzite" has been extensively used for the magnetite-rich variety of Jõhvi gneisses and is still used by some authors. In the case where magnetite and quartz with a minor amount of other minerals (garnet, micas, feldspars) form micro-layered rock asso- 


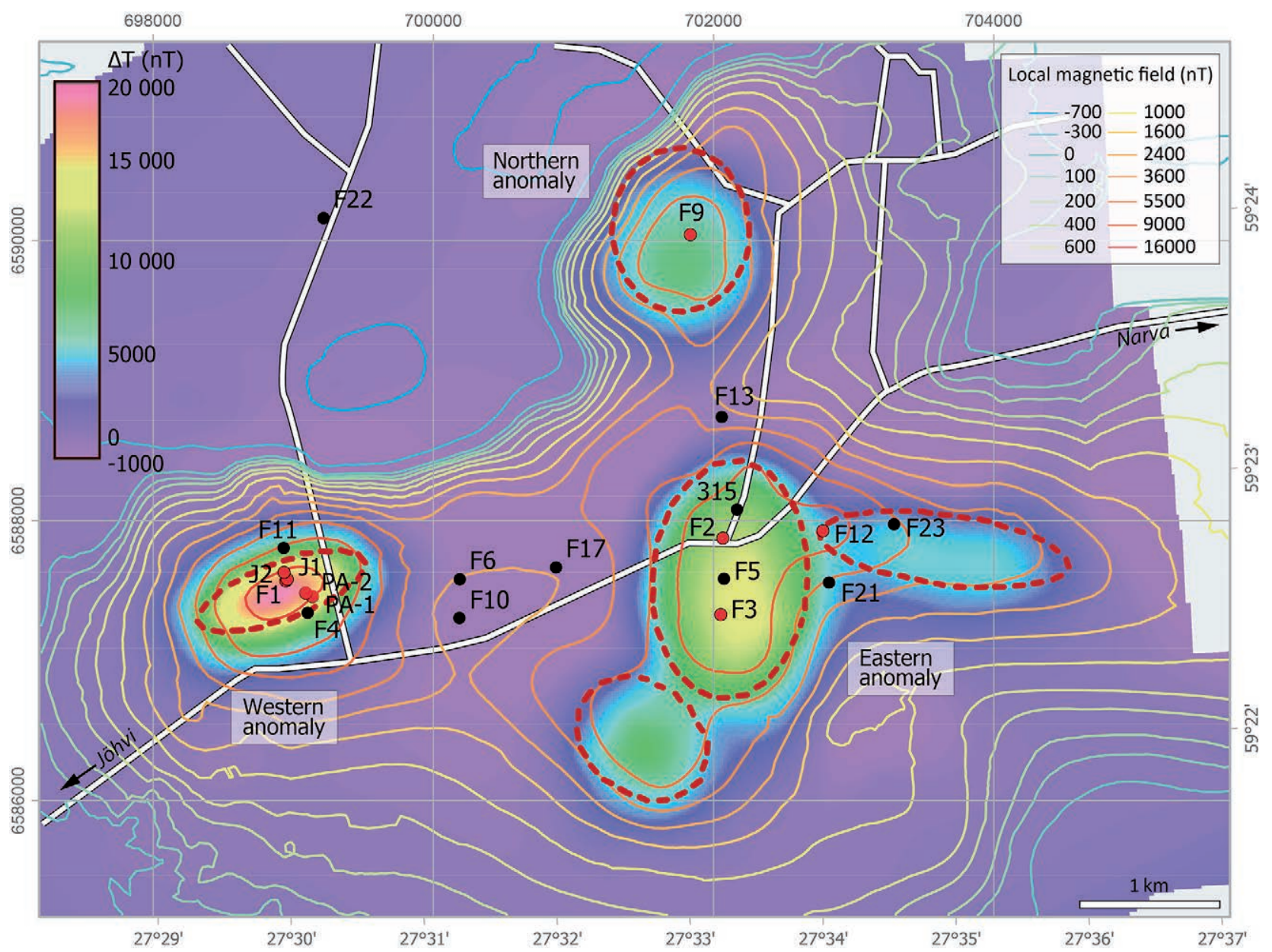

Fig. 2. The Jõhvi Magnetic Anomaly with five elliptic cylinders (red dashed lines) showing the surface projection of the modelled orebodies indicated by the partial anomalies. Locations of boreholes are shown as dots, where red colour indicates the occurrence of magnetite-rich gneiss. Modified from [Plado et al., 2020]

ciations e. g., Banded Iron Formations, this term accurately characterizes the rock type. Although the mineralization in Jõhvi rocks could originate from the previously formed iron-rich sedimentary formation, including magnetite quartzites, the metamorphic processes have resulted in foliated rocks that should be considered as gneisses.

By mineralogy, the British Geological Survey defines quartzite as psammites containing more than $80 \%$ quartz [Robertson, 1999], while the US Geological Survey describes it as a rock containing $>75 \%$ quartz [North..., 2004]. The term "quartzite" is also used for quartz-cemented quartz arenites. In the case of Jõhvi rocks, the term "magnetite quartzite" is somewhat misleading as discussed by Soesoo et al. [2021a]. The studied magnetite-rich rocks are gneisses containing plagioclase (up to $35 \%$ ), other feldspars, pyroxenes (up to $20 \%$ ), garnet and sulphide ore minerals along with magnetite and hematite. In this article, we use the term magnetite-gneisses instead.

\section{Material and methods}

The data presented here is based on the analysis of two new inclined boreholes drilled in 2019 and 2020. The drilling program was conducted by the Geological Survey of Estonia to gain new oriented core material in order to assess the potential of the iron occurrence and verify the historical interpretation of the magnetic body in the western part of the Jõhvi Magnetic Anomaly. Based on the interpretation of the magnetometric studies [Plado et al., 2020], two $770 \mathrm{~m}$ long boreholes with an azimuth of $258^{\circ}$ and dip angle of $58^{\circ}$ were drilled to intersect the magnetic body.

Drill cores were described, and mineralized intervals were distinguished using comprehensive data collected from the borehole and the drill core e. g., borehole geophysical logging results, dry bulk density and magnetic susceptibility of core samples, handheld XRF (X-Ray fluorescence spectrometer) logging results and $\mathrm{XRD}$ 
(X-Ray diffraction) analysis together with thin sections. In addition, more than 1700 measurements of the structural features like schistosity planes of the gneisses, granitic vein directions, and natural fracture surface planes were carried out using a core goniometer.

For the geochemical analysis, comprehensive QA/QC procedures were followed during sampling and an accredited commercial laboratory was contracted to report the results according to the international reporting standards. We analysed 110 quarter core samples using lithium metaborate or sodium peroxide fusion together with ICP-MS or ICP-OES analysis for major and trace elements and fire assay analysis for precious metals ( $\mathrm{Au}, \mathrm{Pt}$, $\mathrm{Pd})$. Magnetite content in the samples was determined by Satmagan analysis. Sample preparation and analysis were carried out in Actlabs, Canada, performing the following analytical packages WRA ICP 4B, Ultratrace 7, 1C-Exploration and Satmagan Test [Actlabs, 2021].

For a more detailed description of specific features in mineralized intervals, scanning electron microscope (SEM) imaging using a variable pres- sure Zeiss EVO MA15 SEM equipped with Oxford $\mathrm{X}$-MAX energy dispersive detector system (EDX) and AZtec software for element analysis was performed at the University of Tartu.

\section{Structural features of the Jõhvi Zone}

Characterization of structural features in the crystalline section of the Jõhvi boreholes is based on visual examination and goniometer measurements of the oriented drill cores. The results of 167 individual measurements of schistosity planes were converted to true angles using the downhole survey data and plotted on stereographic nets. The structural data of schistosity planes were mainly collected from mineralized sections of the drill core.

The distribution of dip angle measurements shows that the schistosity of the mineralized rock is subvertical, thus confirming the historical interpretation of the dipping directions, which were described mainly based on geophysical interpretations. However, the dip azimuth (Fig. 3) of the mineralized sections is not very well defined towards
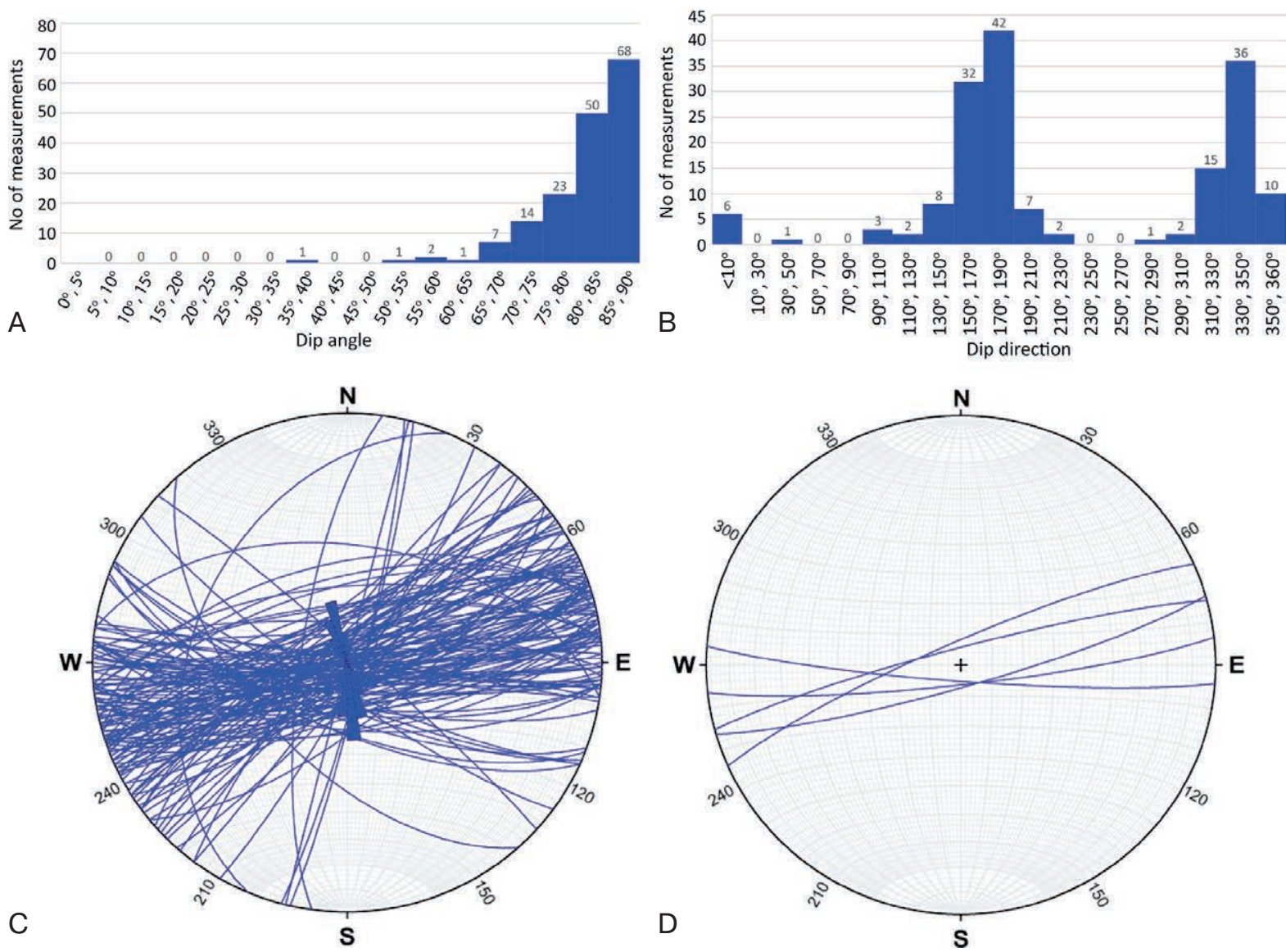

Fig. 3. Structural planes of schistosity in the mineralized sections in boreholes PA-1 and PA-2. A) Distribution of the dip angle; B) Distribution of the dip azimuth; C) All measured planes (167) plotted on stereonet together with a rose plot showing the distribution of the dip angle measurement results; D) Predominant planes plotted on stereonet 
the south. The dipping angle of schistosity commonly varies between and sometimes within separate rock intervals. However, the main dip directions point to southern and northern sections, possibly indicating the $\mathrm{N}-\mathrm{S}$ compression direction of folding.

\section{Main rock types of the Jõhvi drill cores}

Based on the detailed study of two new drill cores (PA-1 \& PA-2), a number of rock types can be distinguished within ca 500 m crystalline rock section (Fig. 4). Rock types include amphibolebiotite-, garnet-amphibole-, pyroxene-amphibole-, biotite- and biotite-feldspar-, garnet-biotiteand garnet-biotite-feldspar-, biotite-feldspar-alumogneisses, pyroxene-, amphibole-, garnet-, garnet-biotite-plagioclase-gneisses, magnetitegneisses, and granitic veins and larger intrusions cutting through the complex.

Amphibole-gneisses are one of several rock types that host magnetite mineralization (Tab. 1, Fig. 4). According to XRD and thin section studies, amphibole gneisses contain up to $35 \%$ magnetite with an average of $24 \%$ in the studied 19 samples.

Biotite-amphibole gneisses are commonly slightly migmatized. The rock comprises amphi- bole (mainly hornblende, $20 \%$ on average), quartz (17-46\%), K-feldspar (2-12\%), and magnetite. Biotite (4\% on average) and fine-grained garnet can also be observed. Generally, fine-grained magnetite is common (11-28\%), however, there also occur semi-massive aggregates. Visible aggregates of iron sulphides (pyrite or pyrrhotite) are present. Although pyroxene and/or garnet can dominate the lithology composition over short interval distances, the biotite concentration is more uniform and consistent throughout the drill core.

Garnet-amphibole gneisses are fine to medium-grained, slightly migmatized, foliated, black or reddish-black rocks. Garnet and magnetite are abundant as fine grains with an average concentration of 11 and $15 \%$, respectively. In addition, quartz (10-50\%), pyroxene (up to $10 \%$ ), K-feldspar, plagioclase and biotite occur in these rocks.

Pyroxene-amphibole gneisses are similar to garnet-amphibole gneisses. Although they have been described in historical boreholes $\mathrm{F} 1$ and $\mathrm{J}-1$, they were not identified in the new boreholes PA-1 and PA-2. Compared to other amphibole-gneisses, quartz, as well as magnetite content (30-67 and 12-35\%, respectively), are higher in pyroxene-amphibole gneisses. The pyroxene content varies from 4 to $10 \%$ and garnet from 2
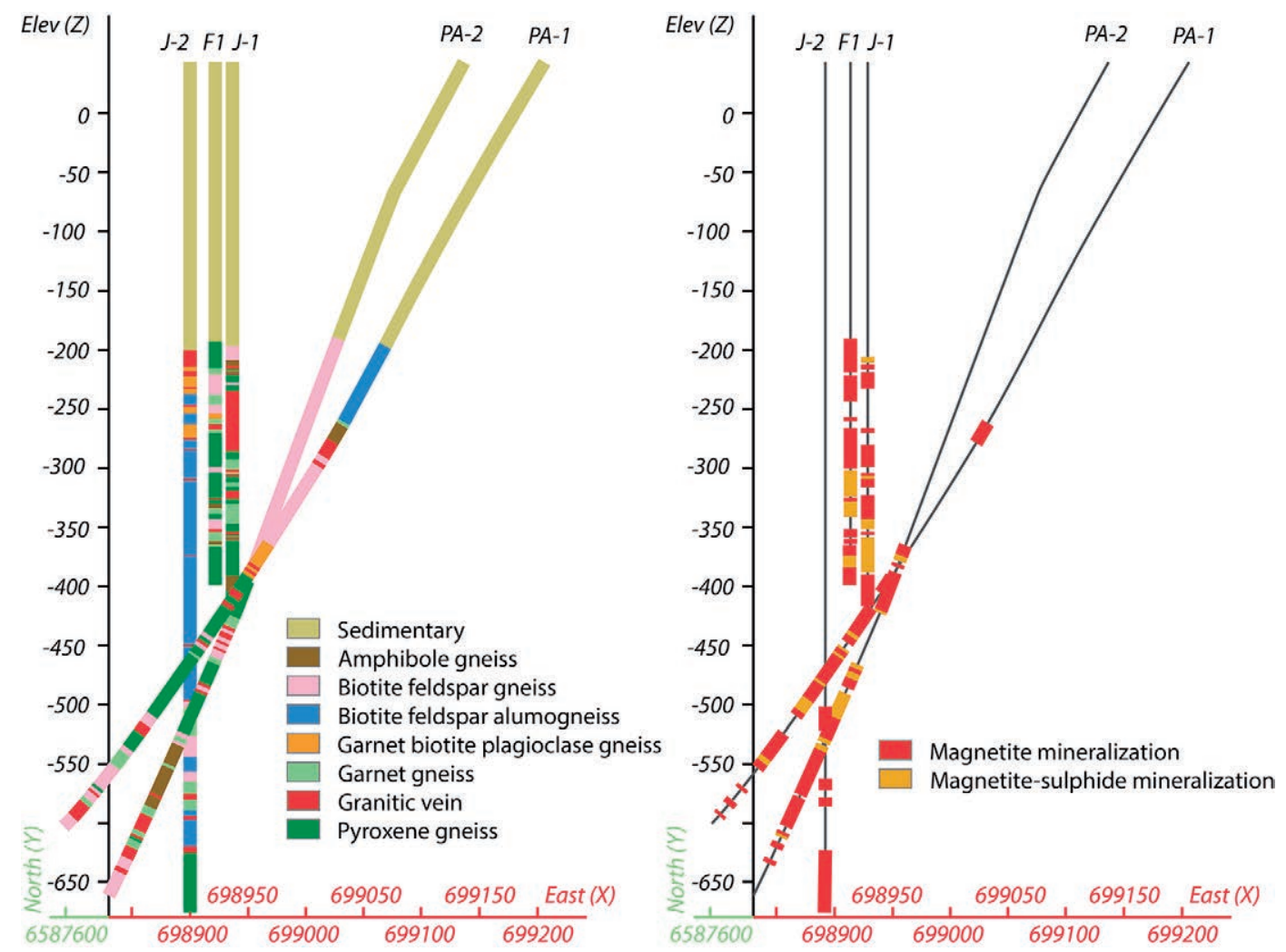

Fig. 4. Sketch map of historical (J-1, J-2, F1) and recent (PA-1, PA-2) boreholes drilled into the western part of the Jõhvi Magnetic Anomaly. Showing the main rock types (left) and magnetite and magnetite-sulphide mineralized sections (right) 
Table 1. Summary of significant layers with high iron content (as $\mathrm{Fe}_{2} \mathrm{O}_{3}$ ) of the drill cores PA-1 and PA-2. Rock types and mineralization intervals can be followed in Fig. 4

\begin{tabular}{|c|c|c|c|c|c|}
\hline \multirow{2}{*}{ Borehole } & \multirow{2}{*}{ Mineralized layer, m } & \multirow{2}{*}{ True thickness, m } & \multicolumn{2}{|c|}{$\mathrm{Fe}_{2} \mathrm{O}_{3}(\mathrm{wt} \%)$} & \multirow{2}{*}{ Rock type } \\
\hline & & & Min & $\operatorname{Max}$ & \\
\hline \multirow{8}{*}{ PA-1 } & $346.95-367.03$ & 10.04 & 24.11 & 34.00 & Grt-Amp gneiss \\
\hline & $506.02-517.10$ & 6.25 & 42.11 & 44.67 & Grt-Px gneiss \\
\hline & $534.90-570.37$ & 12.13 & 22.63 & 43.69 & Grt-Px gneiss \\
\hline & 576.69-646.64 & 23.92 & 30.81 & 52.80 & Grt-Px gneiss \\
\hline & $666.54-682.26$ & 5.38 & 34.11 & 38.72 & Grt-Px gneiss \\
\hline & 683.63-701.98 & 6.28 & 20.98 & 32.09 & Px-Grt gneiss \\
\hline & $725.25-727.10$ & 0.63 & 29.92 & 45.90 & Mag gneiss \\
\hline & $738.80-743.21$ & 1.51 & 29.83 & 34.08 & Px-Grt gneiss \\
\hline & Total true thickness & 66.14 & & & \\
\hline \multirow{6}{*}{ PA-2 } & $443.65-456.88$ & 4.52 & 34.10 & 45.70 & Grt-Px gneiss \\
\hline & $467.70-503.53$ & 12.25 & 26.93 & 42.44 & Grt-Px gneiss \\
\hline & $552.60-571.35$ & 4.85 & 26.17 & 56.59 & Px and Grt-Px gneiss \\
\hline & $578.92-624.85$ & 11.89 & 25.21 & 48.78 & Grt-Px gneiss \\
\hline & $626.70-693.40$ & 17.26 & 21.86 & 47.23 & Bt-Amp gneiss \\
\hline & 717.70-723.32 & 1.45 & \multicolumn{2}{|c|}{22.46} & Amp-Grt gneiss \\
\hline & Total true thickness & 52.22 & & & \\
\hline
\end{tabular}

Note. Grt - garnet; Amp - amphibole; gn - gneiss; Px - pyroxene; Mag - magnetite; $\mathrm{Bt}$ - biotite.

to $17 \%$. However, pyroxene occurs more consistently in the lithology.

Biotite-feldspar gneisses are generally strongly migmatized, with K-feldspar and plagioclase present as porphyroblasts (up to 43 and $16 \%$, respectively). Quartz content is usually below $20 \%$. Chlorite, pyroxene, cordierite, and apatite may also be present. The biotite is fine-grained and foliated, while the coarse-grained feldspars commonly have a porphyroblastic texture.

Biotite-quartz-feldspar gneisses are generally strongly migmatized. The main minerals forming the rock are K-feldspar (28-67\%), plagioclase (12-33\%), quartz (4-36\%), biotite (3-10\%), garnet $(1-2 \%)$, and chlorite $(0.5-4 \%)$. In new boreholes, bleaching halos are visible in the margins of joints (408 to $420 \mathrm{~m}$ in PA-1, 288.5 to $295 \mathrm{~m}$ in PA-2). Magnetite dissolution and hematite formation have also been described by Soesoo et al. [2021a].

Garnet-biotite-feldspar gneisses are commonly strongly migmatized, fine to coarse-grained and foliated rocks. Along with coarse-grained K-feldspar crystals, fine- to medium-grained garnet can also be observed. In places, garnet forms aggregates up to several centimetres in diameter. The main rock-forming minerals are K-feldspar (3-87\%), biotite (4-22\%), garnet (up to $37 \%$ ), plagioclase, amphibole, cordierite, sillimanite, chlorite, and calcite. Large sulphide mineral and magnetite aggregates are found in several locations in both boreholes.
Garnet-biotite gneisses have only been described in historical boreholes $\mathrm{J}-1, \mathrm{~J}-2$ and $\mathrm{F} 1$. Garnet-biotite-gneiss is strongly migmatized and biotite-rich, and may in addition to garnet contain magnetite. In PA-1 and PA-2, feldspar is always present in garnet- and biotite gneisses.

Alumogneisses (aluminiferous gneisses) were logged as separate rock types in contrast to biotite- and biotite-feldspar gneisses due to the distinctive abundance of aluminium-rich minerals such as cordierite, sillimanite, and andalusite.

Biotite-feldspar alumogneisses are generally medium-grained, moderately foliated, dark-coloured rocks. As PA-1 intersects the biotite-feldspar alumogneisses from the surface of the crystalline rocks, distinct reddish and yellowish colours caused by heamatization can be observed. These gneisses have a varying mineral composition of K-feldspar (6-60\%), plagioclase (10-45\%), quartz (17-70\%), biotite (8-15\%), and aluminiferous minerals (sum of cordierite, sillimanite, andalusite $>10 \%$ on average). Some graphite, muscovite, apatite, monazite, zircon, pyrite, and magnetite grains may be present. These rocks are moderately or strongly migmatized. Bands of coarse-grained K-feldspar together with quartz are common. Thin hairline veins and fractures filled with clay minerals, calcite, or fine-grained quartz occur in the upper part of drill core PA-1. According to their characteristics, aluminium-rich gneisses can be classified as paragneisses produced from a clay-rich and sand-rich sedimentary protolith. 


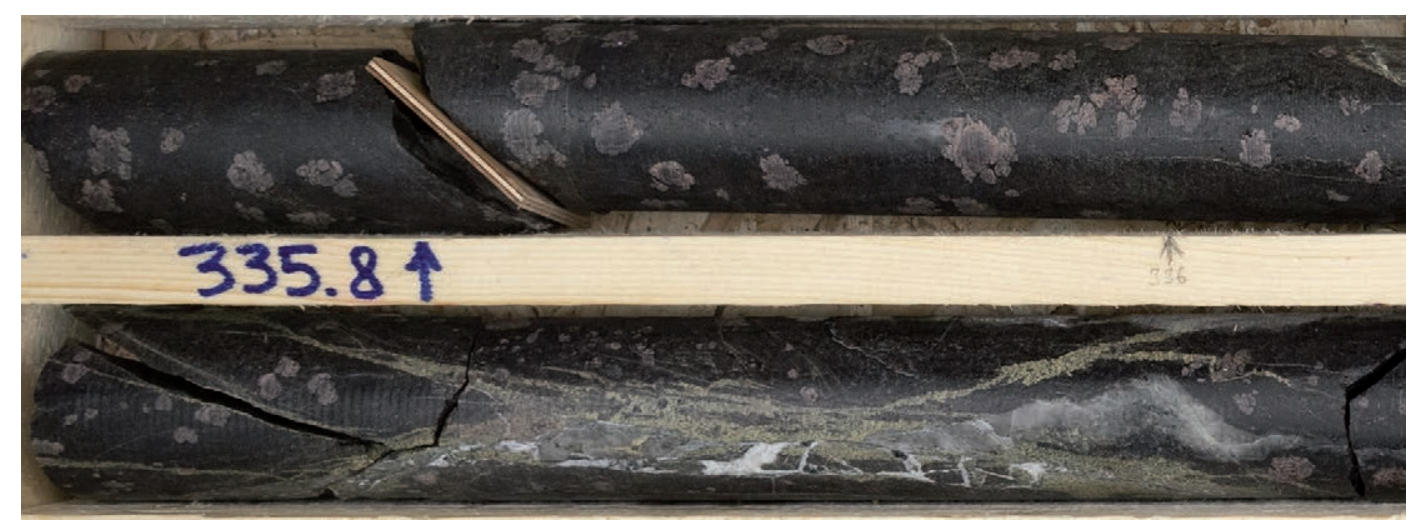

Fig. 5. Garnet porphyroblasts in garnet-biotite-plagioclase gneiss together with calcite and chlorite veins

Garnet-biotite-plagioclase gneisses are variably migmatized, dark-purple-grey in colour and mottled; they are foliated and generally porphyroblastic rocks. Medium to very coarse porphyroblasts of garnet are noted. Garnet is usually anhedral, sometimes elongated, and contains inclusions of magnetite, zircon, quartz, galena, and monazite. Inclusions commonly form helical trails ("snowball structures") suggesting that the porphyroblasts have enclosed adjacent minerals from the matrix as they grew. In places, garnet grains can be aggregated to bands several centimetres thick. The main rock-forming minerals are plagioclase (17-52\%), quartz (5-37\%), biotite (10-48\%), garnet (up to $8 \%$ ), chlorite (2-6\%), calcite, and amphibole. Anastomosing carbonate veining, feint conjugate hairline calcite veinlets and related chloritization are observed in several intervals (Fig. 5).

Amphibole-garnet gneisses are fine to medium-grained, dark red, moderately foliated rocks that can be cut by thin single carbonate and sulphide (pyrite and pyrrhotite) veins. In addition to garnet (up to $45 \%$ ), amphiboles (up to $30 \%$ ), and quartz (up to $60 \%$ ) are the dominant minerals. Lesser amounts of pyroxene, biotite, K-feldspar, pyrite, and pyrrhotite occur in this rock. Garnet-gneisses are mainly fine-grained brownish foliated rocks consisting predominantly of garnet (up to $62 \%$ ) and quartz (up to $65 \%$ ). Plagioclase, biotite, pyrite, pyrrhotite, and magnetite may also occur. In several cases, medium to coarse $(>2 \mathrm{~mm})$ sized pyrite and pyrrhotite grains are observed.

Pyroxene-garnet gneisses and pyroxene gneisses are two of the major rock types hosting magnetite mineralization (Tab. 1). Generally, they are dark-red or black, foliated, fine- to medium-grain rocks with variable mineralogy of magnetite (up to $30 \%$ ), garnet, pyroxene, amphibole, feldspar, quartz, pyrite, and pyrrhotite. While the magnetite grains are fine, the pyrite and pyrrhotite occur as medium-size grains with some rare occurrences of large semi-massive aggregates. Single hairline calcite veins cut through the rocks in several places. In addition, pyrite, pyrrhotite, siderite, apatite, calcite, biotite, chlorite, and plagioclase have been described in thin sections.

Pyroxene-containing gneisses are generally medium-grained dark rocks that coincide often with garnet-pyroxene gneisses but contain more quartz (occasionally up to $72 \%$ ), less than $5 \%$ garnet, and cordierite and K-feldspar can be present. Along with magnetite, pyrrhotite and pyrite can be seen. Migmatization is rare in pyroxene-gneisses. Pyrite and pyrrhotite are also found in the thin veins cutting the core and on the surfaces of fractures as thin mineral films.

Magnetite-quartz gneisses are described in only two metres of both drill cores. The rock is strongly migmatized, coarse-grained, black and grey in colour, and consists mostly of magnetite, quartz, and plagioclase. The rock is often cut by thin carbonate veins.

Magnetite and sulphide minerals can be found sporadically in all the described rock types. Yet, continuous mineralization, which is also a subject for mineral exploration, is related to certain rock types e. g., garnet-pyroxene, pyroxene-garnet, pyroxene gneisses, or to a lesser extent, garnet-amphibole, amphibole-garnet and biotite-amphibole gneisses. In boreholes PA-1 and PA-2, mineralized layers were identified using the logging results of magnetic susceptibility, dry bulk density and handheld XRF together with laboratory geochemical and mineralogical analysis (Tab. 1). For every mineralized layer distinguished, the true thickness was calculated using the apparent thickness of the mineralized layer and the angle between the schistosity planes and the long axis of the drill core. 


\section{Main ore minerals in the Jõhvi drill cores}

Ore mineral microscopy study in reflected light has been published in a previous study [Soesoo et al., 2021a]. The study used several ore mineral features such as reflectivity, apparent colour, bireflection, anisotropy, and internal reflections. In the Jõhvi drill cores, optically isotropic magnetite occurs as anhedral grains elongated along rock fabric, interstitially filling the space between other minerals by forming patches of up to several millimetres in size or embedded in silicate minerals as rounded inclusions with the size of 20-100 $\mu \mathrm{m}$. In addition, magnetite can also be found as tiny platelets along grain edges and cleavage planes of amphibole and biotite. The patches of magnetite are often oriented as distinct bands alternating with silicate mineral dominated layers. In some sections, magnetite is altered into anisotropic and bireflective hematite along grain edges, cracks and cleavage planes [see Soesoo et al., 2021a]. In places, hematite also appears as colloform filling of $5 \mathrm{~mm}$ wide veins cutting subparallel to the main rock fabric and cogenetic intensive alteration of magnetite close to the veins [see figures in Soesoo et al., 2021a].

The study of the two new drill cores has confirmed that magnetite appears in a variety of types of gneisses. Magnetite $\left(\mathrm{Fe}_{3} \mathrm{O}_{4}\right)$ can be found in various gneisses with different mineral assemblages. However, notable intervals with high magnetite content are usually represented by garnet-pyroxene, pyroxene-garnet, pyroxene, garnet-amphibole, garnet-biotite-feldspar, and amphibole-garnet gneisses. These rocks are commonly fine or medium-grained, in most cases manganiferous, with thin foliated beds/layers where quartz is alternating with dark minerals (Fig. 6).

Sulphide minerals often occur together with magnetite in garnet-pyroxene, pyroxene-garnet,
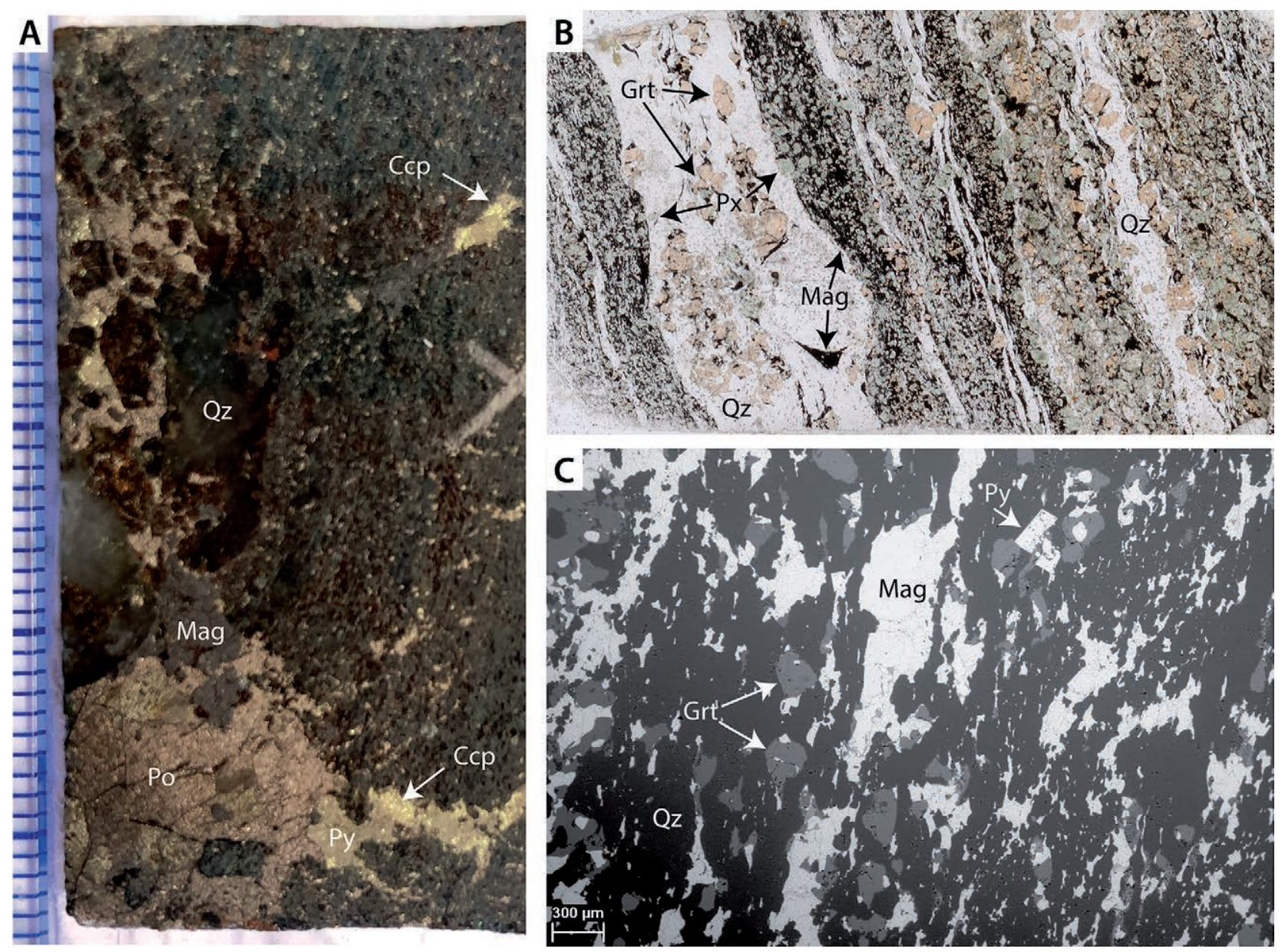

Fig. 6. A) Magnetite-sulphide mineralization in drill core PA-2 from the Jõhvi zone showing semi-massive sulphides (Po - pyrrhotite, Py - pyrite, and Ccp - chalcopyrite) and magnetite (Mag) together with fine-layered magnetite, quartz $(\mathrm{Qz})$, garnet (Grt), and pyroxene (Px) gneiss with disseminated medium sulphide grains. B) Plain-polarised light photomicrograph of a foliated banded zone of magnetite, garnet, quartz, and pyroxene in a thin section from drill core F-1, Jõhvi Magnetic Anomaly. C) Scanning electron microscope photomicrograph of iron mineralization in a thin section from drill core PA-1 
and pyroxene gneisses. However, sulphide mineralization can also occur in non-magnetic biotite- and biotite-feldspar gneisses and as medium to large grains or aggregates in granitic veins.

Sulphides are present mostly as anisotropic pyrrhotite $\left(\mathrm{Fe}_{(1-x)} \mathrm{S}\right)$ and isotropic pyrite $\left(\mathrm{FeS}_{2}\right)$, which occasionally exhibits weak anisotropy levels. Pyrite appears as sub- to euhedral crystals or interstitial patches between other grains, commonly closely related to pyrrhotite, magnetite, and garnet (Figs. 7 \& 8). Together with magnetite and pyrrhotite, they form ore mineral-rich bands. Brittle fracturing has occurred with pyrite, pyrrhotite, and magnetite filling the space. Pyrite and pyrrhotite also appear as fillings in later-stage cross-cutting brittle fractures. Occasional chalcopyrite, galena, and sphalerite grains were found in magnetite-rich drill core sections of historical drill cores $\mathrm{F}-1$ and $\mathrm{F}-5$.

In the new boreholes PA-1 and PA-2, indications of chalcopyrite $\left(\mathrm{CuFeS}_{2}\right)$, arsenopyrite (FeAsS), and iron arsenide - loellingite, $\mathrm{FeAs}_{2}$ can be observed (Figs. 8 \& 9). While the chalcopyrite appears together with pyrite and pyrrhotite, loellin- gite and arsenopyrite seem to be commonly related to quartz-feldspar veining.

\section{Geochemistry of the Jõhvi rock type}

The analysed samples were distributed into three classes where a) magnetite mineralization (69 samples) was assigned to samples with high magnetic susceptibility, b) magnetite-sulphide mineralization (37 samples) is represented by magnetite-rich samples with macroscopically visible sulphide grains or aggregates, and c) host-rock samples (4 samples) were taken from the adjacent intervals of mineralization. As the main geochemical differences between mineralized and host-rock have been described previously [Soesoo et al., 2021a], this study focuses on the characteristics of magnetite and magnetite-sulphide mineralization. Examples of bulk sample geochemical composition showing variability between and within these mineralization classes are given in Table 2 .

The $\mathrm{SiO}_{2}$ content ranges from 24.6 to 60.4 wt $\%$ with an average of 46 wt $\%$ for all mineralized samples (Fig. 10). Iron $\left(\mathrm{Fe}_{2} \mathrm{O}_{3}\right)$ content ranges from 21.0

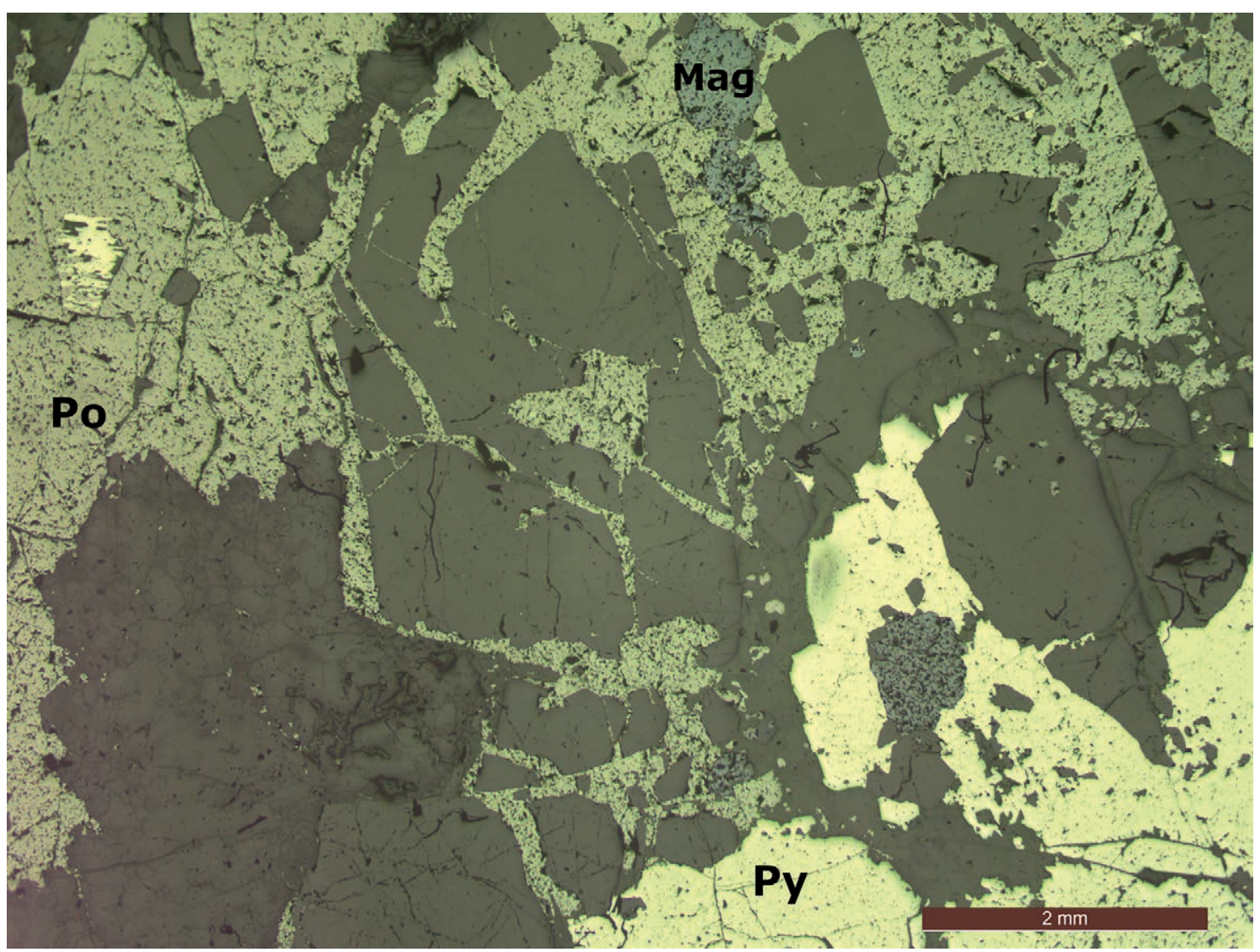

Fig. 7. Photomicrograph (in plane-polarized reflected light) of garnet-pyroxene gneiss with pyrrhotite (Po), pyrite (Py), and magnetite (Mag) filling the gaps between rock-forming minerals. Drill core PA-2, depth $-447.3 \mathrm{~m}$ 
$\mathrm{Fe}$

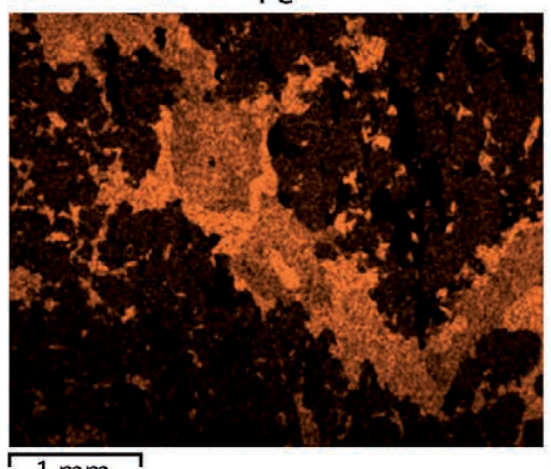

$\mathrm{Cu}$

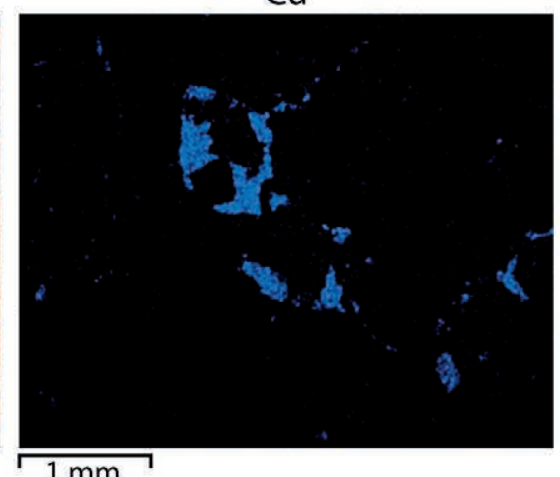

S

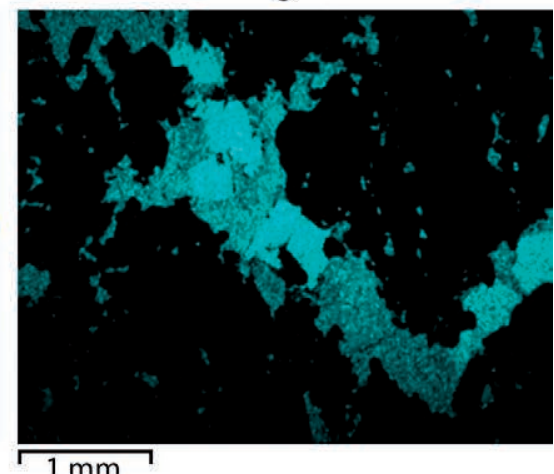

Fig. 8. Elemental mapping of Fe, S, and Cu by scanning electron microscope. Pyrite, pyrrhotite, and chalcopyrite (blue on the Cu element map) in garnet-pyroxene gneiss can be recognized in the X-ray maps. Drill core PA-2, depth 565.09-565.12 m

$\mathrm{Fe}$

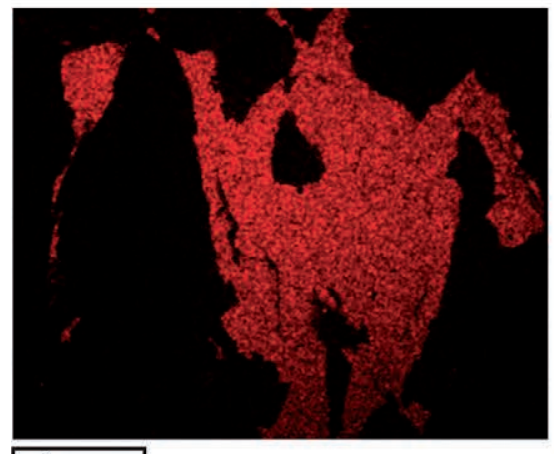

$\longdiv { 1 \mathrm { mm } }$

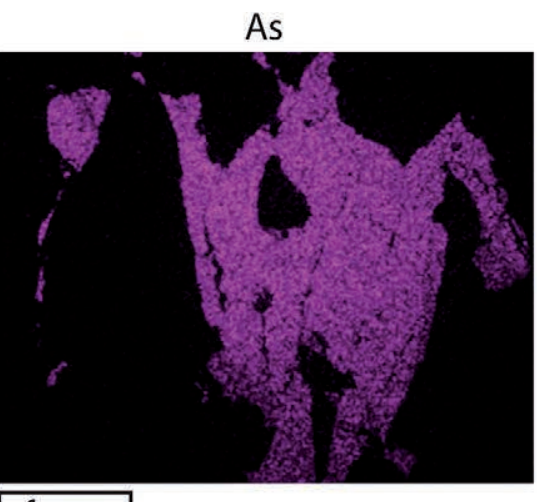

$1 \mathrm{~mm}$
S

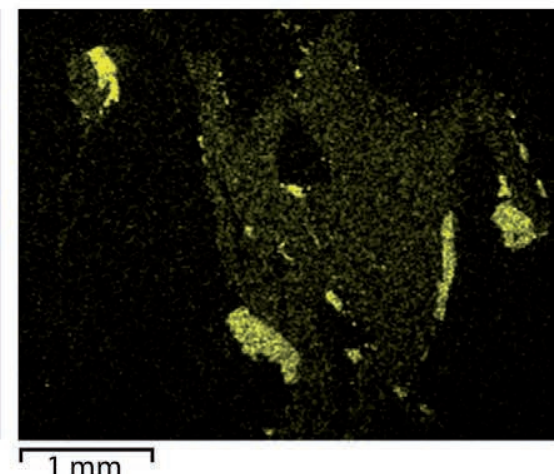

Fig. 9. Elemental mapping of $\mathrm{Fe}, \mathrm{As}$, and $\mathrm{S}$ by scanning electron microscope. A majority of arsenic indications are related to iron arsenide (loellingite), not arsenopyrite (yellow on the S element map).

Drill core PA-1, depth 417.67-417.74 m

to $56.6 \mathrm{wt} \%$, where no clear difference between magnetite or magnetite-sulphide mineralization can be seen. $\mathrm{Fe}_{2} \mathrm{O}_{3}$ is in negative correlation with $\mathrm{Al}_{2} \mathrm{O}_{3}$ and $\mathrm{CaO}$ ( Tab. 3). Highly variable $\mathrm{MnO}$ content of $0.16-13.57$ wt $\%$ in all mineralized samples suggests that the mineralization occurs in different rock types, including gneisses with a remarkably high content of garnet end-member spessartine. $\mathrm{TiO}_{2}$ content shows that magnetite mineralization can occur in gneisses of variable mineral composition (0.02-1.68 wt\%), while sulphide minerals are more strictly related to the more homogenous rocks with low $\mathrm{TiO}_{2}$ wt $\%$ (0.008-0.42 wt\%). The high concentrations are related to a specific highly migmatized magnetite gneiss interval. The average $\mathrm{Al}_{2} \mathrm{O}_{3}$ content in all magnetite and magnetite-sulphide mineralized samples are 4.84 and $3.53 \mathrm{wt} \%$, respectively. $\mathrm{CaO}$ ranges from 1.12 to $11.97 \mathrm{wt} \%$ in all mineralized samples. $\mathrm{K}_{2} \mathrm{O}$ ranges from 0.004 to $5.07 \mathrm{wt} \%$ for magnetite and from 0.002 to 1.85 for magnetite-sulphide mineralized samples. $\mathrm{MgO}$ content varies between
0.28 and 4.92 wt\% for all mineralized samples. Average $\mathrm{Na}_{2} \mathrm{O}$ content is more than twice as much in magnetite mineralized samples than in magnetite-sulphide samples $(0.09$ and 0.20 wt $\%$, respectively). $\mathrm{P}_{2} \mathrm{O}_{5}$ content in all mineralized samples is generally below $0.4 \mathrm{wt} \%$, albeit in three samples it was up to $3.87 \mathrm{wt} \%$.

Higher concentrations of $\mathrm{Cu}$ (up to $3126 \mathrm{ppm}$ ) can be seen in magnetite-sulphide mineralized samples suggesting that some amount of chalcopyrite is present along with pyrite and pyrrhotite. $\mathrm{Ni}$ content in the analysed samples is rather low, ranging from 11.7 to $110.6 \mathrm{ppm}$ except for one sample with $213.2 \mathrm{ppm}$. Co content in magnetite mineralized samples ranges within 13-121 ppm. However, concentrations up to $303 \mathrm{ppm}$ can be seen in samples with sulphide. Similarly to $\mathrm{Co}, \mathrm{Cu}$ and $\mathrm{Sn}$ are also in positive correlation with $\mathrm{S}$ and negative correlation with $\mathrm{SiO}_{2}$. $\mathrm{Cr}$ content is more variable in magnetite mineralized samples than in magnetite-sulphite samples, with concentrations of $62-440 \mathrm{ppm}$ and $65-309 \mathrm{ppm}$, respectively. 


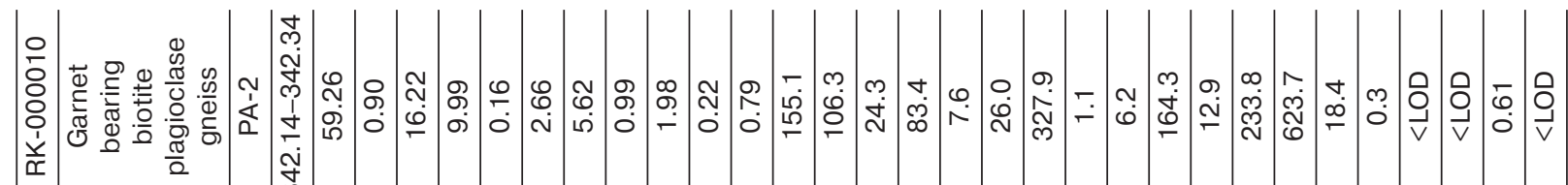

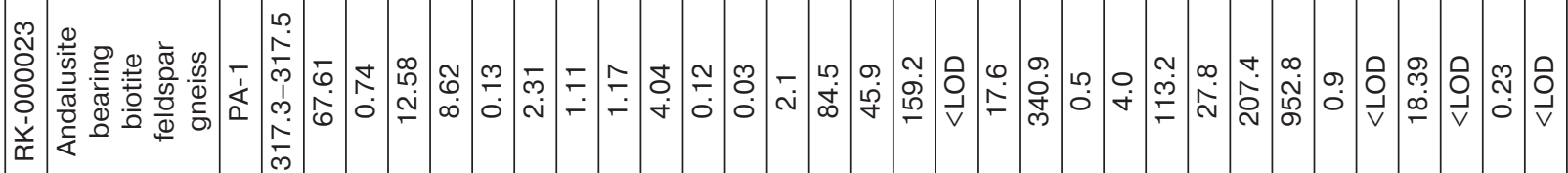
๓

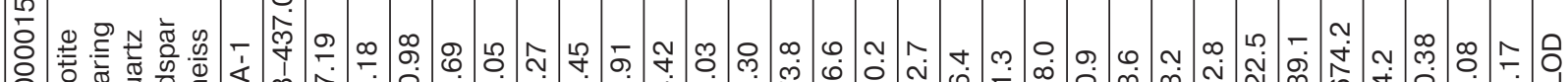

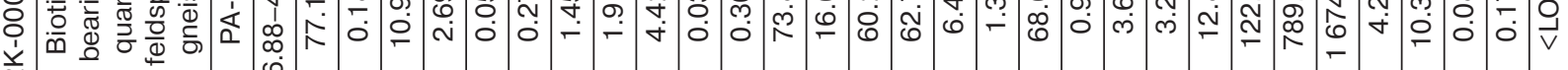
$\frac{\grave{2}}{\widetilde{2}}$

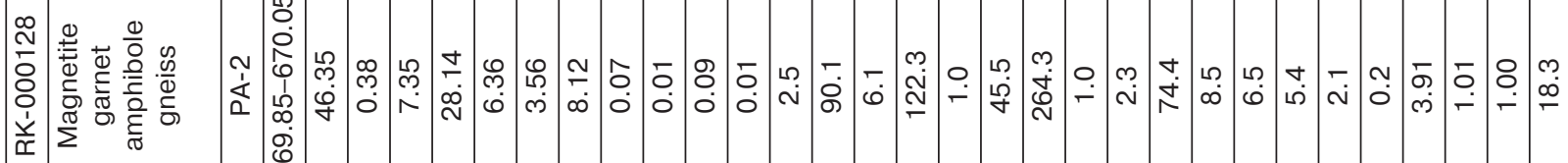

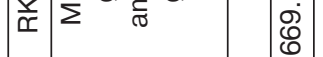

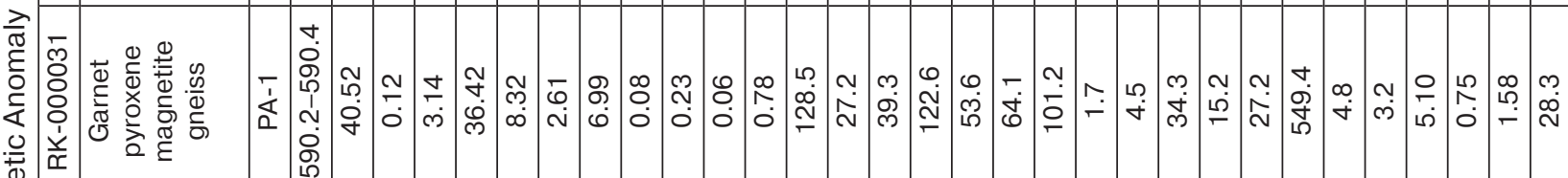

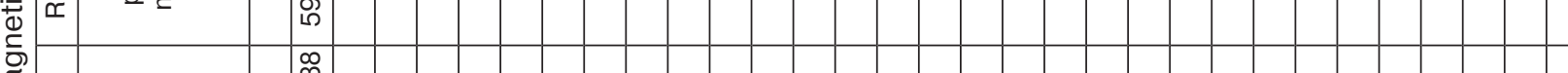

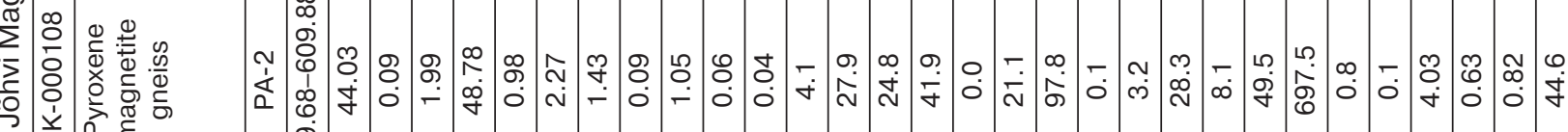

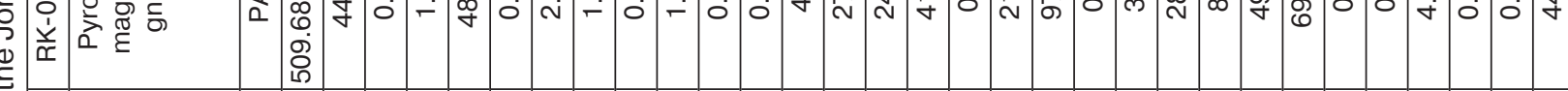

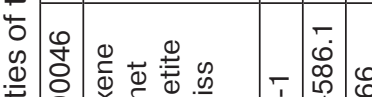

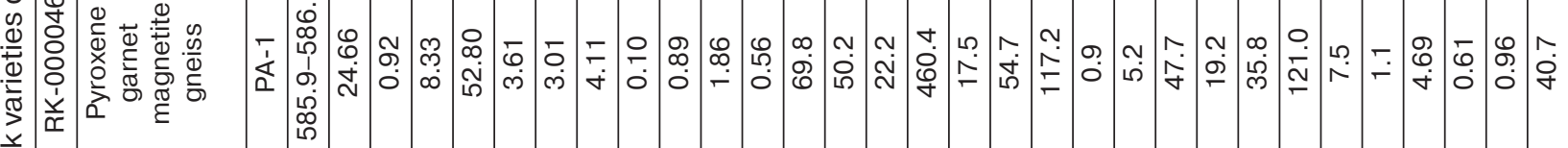

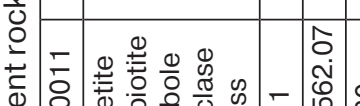

离

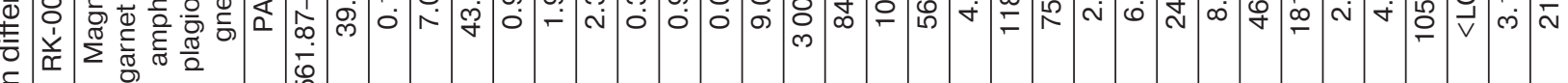

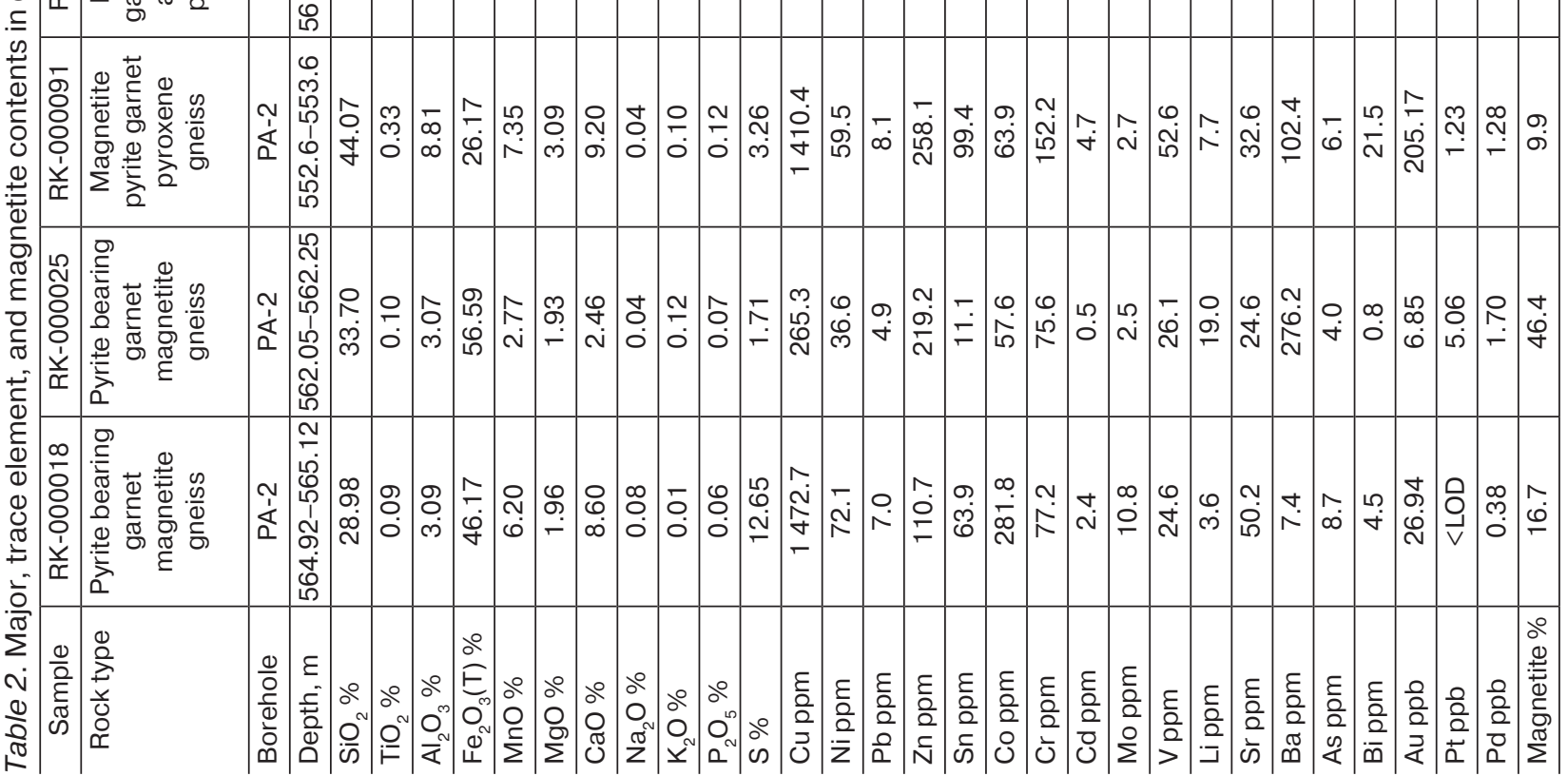




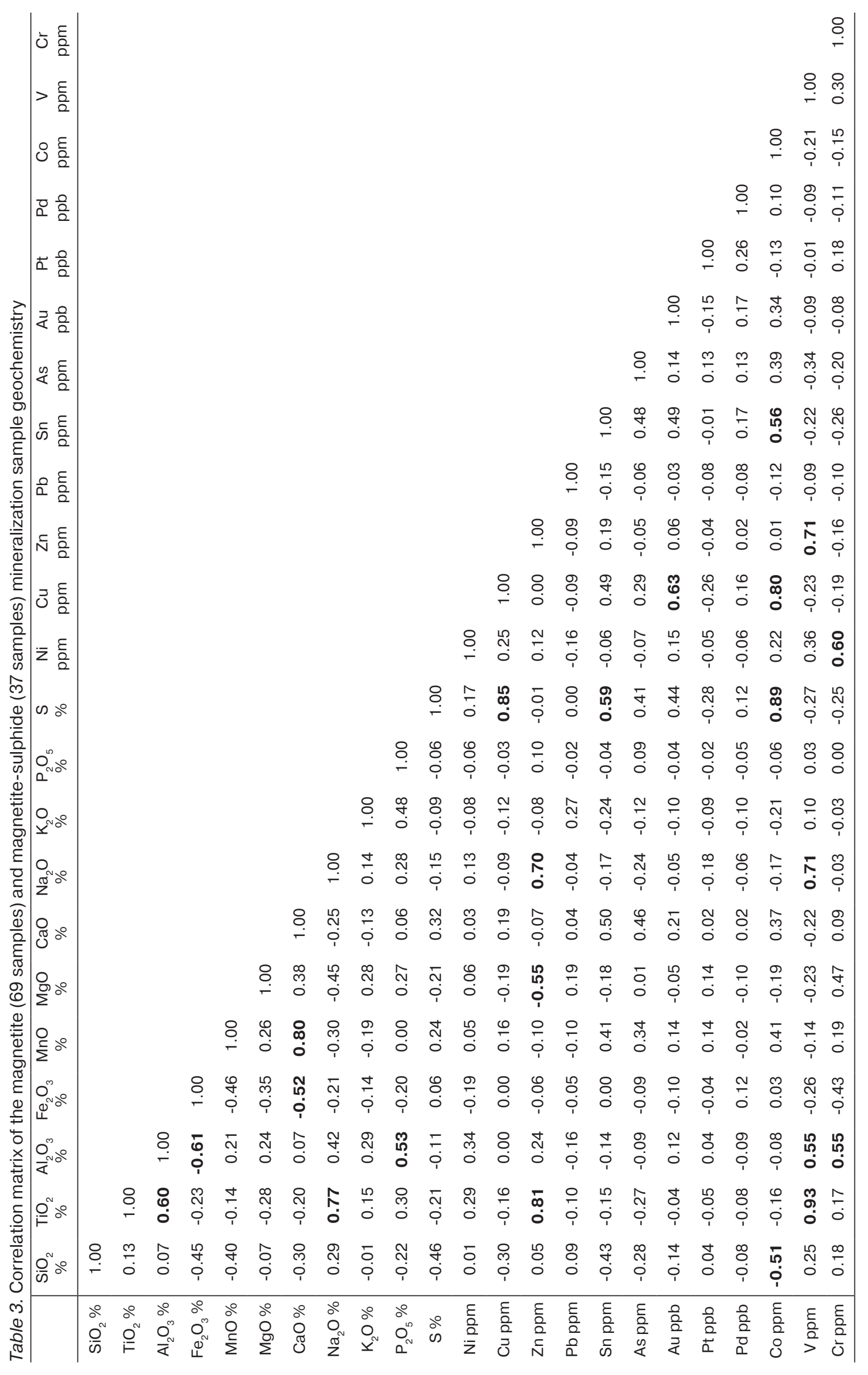



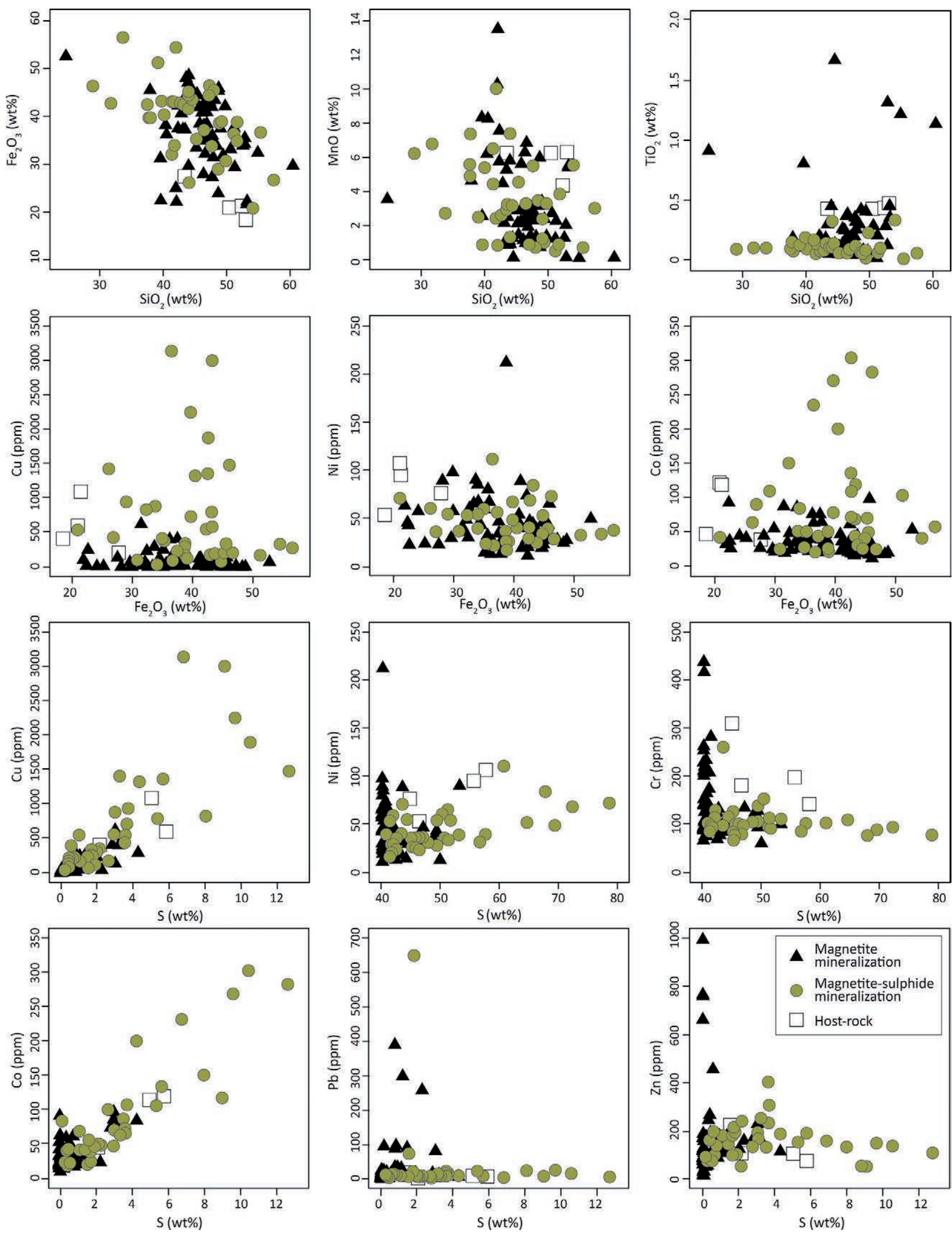

Fig. 10. Geochemical variation plots for selected major oxides and trace elements

$\mathrm{Pb}$ content in mineralized rocks is generally below 100 ppm, except for one magnetite-sulphide sample $(647 \mathrm{ppm})$ and three magnetite minera- lized samples (250-400 ppm). Zn content varies from 20 to $309 \mathrm{ppm}$ in magnetite mineralized samples, except for a few samples ranging within 
404-997 ppm. In samples with magnetite-sulphide mineralization, $\mathrm{Zn}$ content is low, ranging from 57 to $404 \mathrm{ppm}$. Neither $\mathrm{Pb}$ nor $\mathrm{Zn}$ are related to sulphides as there is no positive correlation with $S$ content. However, $\mathrm{Zn}$ is in positive correlation with $\mathrm{V}, \mathrm{TiO}_{2}$, and $\mathrm{Na}_{2} \mathrm{O}$.

\section{Discussion}

Magnetite percentage in 106 mineralized samples was determined by Satmagan analysis, which is based on the saturation magnetization obtained by measuring the total magnetic moment in a high magnetic field. Samples of magnetite mineralization line up, showing a good positive correlation between the total iron content and magnetite percentage, indicating that the iron is strictly related to the magnetite mineralization (Fig. 11). A majority of the magnetite-sulphide mineralization samples follow the same trend, but a group of samples with high sulphur content shows that not all of the total iron content is forming magnetite. Instead, iron can be involved in sulphides, which have to be taken into account when assessing the economic potential of the iron ore occurrence.

Different generations of iron oxides appearing as magnetite or hematite, magnetite to hematite alteration, sulphide precipitation or alteration as a pyrite/pyrrhotite association and minor chalcopyrite, galena, and sphalerite, as well as co-precipitation of sulphides and magnetite indicate a complex redox history [Hall, 1986; Lagoeiro, 2004; Slotznick et al., 2018] of iron-rich rocks in the Jõhvi area. The succession of general geological processes in time and their relations to specific ore-forming processes are not yet clear and definitely need more studies.

A remarkably high arsenic content (1674 ppm) was detected in one $20 \mathrm{~cm}$ long quarter core sample revealing an occurrence of arsenopyrite and loellingite (Fig. 9), which are considered as indicator minerals for Carlin-type gold deposits [Rytuba, 1984]. These minerals occur together with quartz and $\mathrm{K}$-feldspar in a few $\mathrm{cm}$-thick veins in biotite-quartz-feldspar gneisses suggesting that enrichment with arsenic could be related to secondary processes. Also, the generally low correlation seen between base metals e. g., $\mathrm{Ni}, \mathrm{Cu}, \mathrm{Pb}, \mathrm{Zn}$ in mineralized rock can reflect possible remobilization of metals on a local scale during late or postorogenic active processes.

Several of the analysed samples showed an elevated Au content ( $\max 205$ ppb), which is often linked with magnetite-sulphide mineralization having a positive correlation with $\mathrm{S}, \mathrm{Cu}$, and $\mathrm{Sn}$, but does also occur in barren garnet gneisses. The average gold content is, however, low in mag-

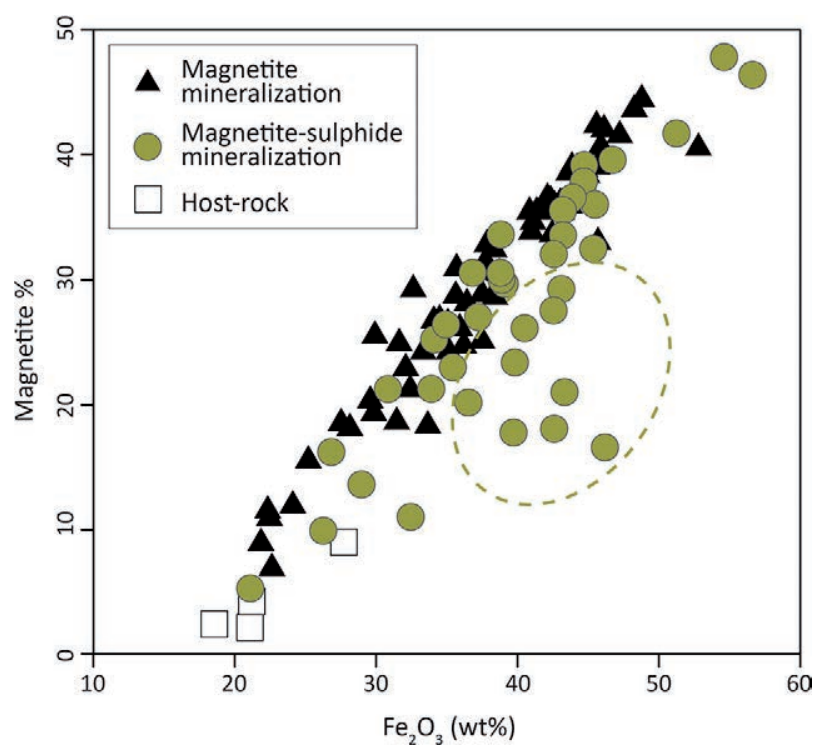

Fig. 11. Positive correlation between magnetite and total iron content in analysed samples. Contour-line showing samples of high iron-sulphide content

netite mineralization samples. Both arsenic and gold anomalies are indications of possible precious metal occurrence in addition to iron-sulphide mineralization and are yet to be more thoroughly studied.

The bulk rock analysis revealed high manganese contents $(0.2-13.6 \mathrm{wt} \%)$ in a number of mineralized samples and on rare occasions in the surrounding gneisses. Manganese- and iron-rich rock types are also known in the Jägala rock complex of the Tallinn Zone [Petersell, 1976]. So far, there is no good explanation for manganese enrichment.

Previously, three distinctly different garnet solid solutions have been distinguished by electron microprobe analysis of the Jõhvi garnet-pyroxenemagnetite rock associations [Soesoo et al., 2021a]:

1. Spess ${ }_{48.1-50.5} \mathrm{Alm}_{20.1-22.3}$ And $_{18.6-21.7}$ Gross $_{0.8-11.1}$ $\operatorname{Prp}_{2.1-4.6}$

2. Alm $_{60.3-72.4} \operatorname{Prp}_{19.6-25.3}$ Spess $_{3.6-7.6}$ Gross $_{0.9-4.3}$ And $_{1.2-3.1}$

3. Alm $_{34.3-34.8}$ Spess $_{33.7-35.5} \operatorname{Prp}_{13.0-13.9}$ Gross $_{9.8-11.1}$ And $_{5.8-7.4}$

The content of MnO in previously studied Jõhvi high-spessartine garnets ranged from 1.6 to 21.15 wt\%. This indicates that high-spessartine garnets form a fundamental part of magnetite bearing pyroxene-garnet gneisses and can be accountable for the high manganese concentrations in the rock. In addition to garnet, another Mn-carrying mineral, ilmenite, has been earlier found in several samples. The previous microprobe analyses show that ilmenite may contain 5 to $35 \mathrm{wt} \%$ of $\mathrm{MnO}$ in the studied Jõhvi rocks [Soesoo et al., 2021a], pointing to the presence of pyrophanite 
$\left(\mathrm{MnTiO}_{3}\right)$, an end member of the ilmenite group. Also, relatively high manganese contents have been described in magnetite grains.

Current geological and geochemical concepts dealing with the mineralization of the Jõhvi Zone refer predominantly to possible similarities with the Bergslagen ore province in Sweden. Geographically, both regions belong to the same crustal structural domain, possibly having similar magmatic-volcanic-sedimentary features [Voolma et al., 2010; Bogdanova et al., 2015; Nirgi, Soesoo, 2019; Soesoo et al., 2021a]. In the Jõhvi area, the metamorphic temperatures (calculated by garnetbiotite geothermometry) were between 650 and $750^{\circ} \mathrm{C}$, and the garnet-biotite-plagioclase-quartz geobarometer yielded the pressure range of 2.9 to 4.9 kbar [Soesoo et al., 2021a].

Rocks in the Bergslagen region have been affected by polyphase ductile deformation and at least two regional phases of folding are proposed [Stålhös, 1981; Beunk, Kuipers, 2012]. The deformation history of the Precambrian basement of Estonia is not well described due to a lack of structural information (so far only two oriented boreholes were drilled in Estonia).

P-T estimates for rocks of the southern Bergslagen are within $500-650^{\circ} \mathrm{C}$ and 2-6 kb [Sjöström, Bergman, 1998; Stephens et al., 2009], while for the northern part the estimates are somewhat higher [Andersson, 1997, 2005]. Geothermobarometry of arsenopyrite and sphalerite in the western part of Bergslagen suggests temperatures and pressures of $525^{\circ} \mathrm{C}$ (between $440-590^{\circ} \mathrm{C}$ ) and ca 3-4 kb, while fluid inclusion entrapment conditions in the ore were determined to vary between 400 and $600{ }^{\circ} \mathrm{C}$ and pressure of $2.8 \mathrm{~kb}$ [Anderson et al., 2014]. There are no P-T estimates based on the Jõhvi zone ore minerals available. However, these general metamorphic conditions are principally similar for both regions.

One of the typical features of the Bergslagen ore province is a spatial association between $\mathrm{Zn}-\mathrm{Pb}-\mathrm{Ag}-(\mathrm{Cu}-\mathrm{Au})$ sulphide deposits and magnetite-rich iron oxide deposits [Jansson, 2011]. The most common type of metal deposit in the Bergslagen ore province consists of associated skarn and metacarbonate iron oxides with varying amounts of manganese [Allen et al., 2003, 2008; Voolma et al., 2010]. Economically important deposit types of the Bergslagen mining district can be subdivided into the following end members with smooth transitions and include banded iron formation, magnetite calc-silicate skarn-, manganiferous skarn- and carbonate-hosted iron ore, apatitebearing iron ore, stratiform and strata-bound $\mathrm{Zn}$ $\mathrm{Pb}-\mathrm{Ag}-(\mathrm{Cu}-\mathrm{Au})$ sulfide ores, and tungsten skarn [Allen et al., 1996].
In the Bergslagen ore province, characteristics corresponding to more than one type sometimes are found in locally limited areas in one and the same deposit. Some iron oxide skarn deposits appear to have developed into quartz-rich iron deposits. Most of the skarns associated with iron oxide minerals, base metal sulphide minerals, and those dispersed through volcanic sequences are currently interpreted as a result of regional metamorphism of interbedded sedimentary, volcanic, and hydrothermally altered rocks, which are not spatially associated with specific events [Allen et al., 2003, 2008]. The poor correlation of major elements and metals, and between different metals in Jõhvi drill cores is probably due to several ore mineralization epochs and the complicated geological history of the volcanogenic-sedimentary basin during the Early Proterozoic.

In the same crustal structural domain, a metallogenic area of Orijärvi is known in Southern Finland. By the time of metamorphism and styles of metallic mineralization, this area is also considered to be an eastern extension of Bergslagen [Latvalahti, 1979; Kähkonen, 2005; Weihed et al., 2005; Bogdanova et al., 2015]. Albeit the Orijärvi area consists of four different types of metallic mineralization e. g., $\mathrm{Zn}-\mathrm{Cu} \pm \mathrm{Pb}$, Au VMS (Aijala, Metsämonttu, Orijärvi), epithermal $\mathrm{Au} \pm \mathrm{Cu}$, banded iron formations (Jussarö, Nyhamn), and skarn iron ores (minor occurrences along the entire Orijärvi area), the magnetite-quartz-Fe silicate banded iron formations at Jussarö and Nyhamn resemble Jõhvi magnetite-rich gneisses in the high abundance of garnet and possibly the primary origin of iron-rich chemical sediments. Moreover, similarly to previous ideas of metallogenesis in the Jõhvi area [Tikhomirov, 1966], skarn iron ores have been described in the Orijärvi area as well. They are, however, not skarns sensu stricto (i. e., formed in contact with and due to an intrusion), but multiply deformed iron formation units that have suffered metamorphic skarnification and recrystallization in contact with chemically reactive lithological units, such as marbles, or are recrystallized carbonate-facies iron formations [Mäkelä, 1989]. These processes are not well understood in the Jõhvi Zone. So, the extensive comparative studies of the Jõhvi and other mineralisation occurrences in Northern Estonia will become relevant in the future after more mineralogical, geochemical and petrological information becomes available on the Estonian basement.

\section{Conclusions}

Magnetite and sulphide mineralization is historically known in the Jõhvi Zone, North-eastern 
Estonia. The mineralized beds have a complicated internal structural outline and a large range of rock varieties. Magnetite and sulphide minerals can be found sporadically in all rock types. Yet, continuous mineralization, which is also a subject for mineral exploration, is related to certain rock types e. g., garnet-pyroxene, pyroxene-garnet, pyroxene gneisses or, to a lesser extent, garnet-amphibole, amphibole-garnet and biotite-amphibole gneisses.

Total iron content $\left(\mathrm{Fe}_{2} \mathrm{O}_{3}\right)$ ranges from 21.0 to 56.6 wt\%. In sulphide-rich mineralized rocks, a significant part of total iron content can be involved in sulphides, which have to be taken into account when assessing the economic potential of the iron ore occurrence.

The distribution of dip angle measurements of the two new drill cores shows that the schistosity of mineralized rock is subvertical; the main dip directions point to southern and northern sections, possibly indicating the $\mathrm{N}-\mathrm{S}$ compression direction of folding.

Sulphide mineralization or alteration as a pyrite/ pyrrhotite association and minor chalcopyrite, arsenopyrite and iron arsenide - loellingite, galena, and sphalerite indicate a complex, possibly multiphase mineralization history of the iron-rich rocks. While the chalcopyrite appears together with pyrite and pyrrhotite, loellingite and arsenopyrite seem to be commonly related to quartz-feldspar veining.

The succession of general geological processes in time and their relations to specific ore-forming processes are not yet clear and need additional studies. Data from two new drill cores support the understanding that the Jõhvi Zone is geologically similar to Bergslagen in Sweden and possibly to Orijärvi in southern Finland.

This study was supported by ERDF and Estonian Research Council via project RESTA20 to TalTech "Genesis and economically valuable metals in polymetal sulphide mineralization in the Precambrian of Estonia“.

\section{References}

Actlabs. Geochemistry Schedule of Services and Fees. 2021. URL: https://actlabs.com/wp-content/ uploads/2021/07/Actlabs-Schedule-of-Services-Euro2021.pdf (accessed: 01.09.2021).

Allen R. L., Lundström I., Ripa M., Simeonov A., Christofferson $H$. Facies analysis of a $1.9 \mathrm{Ga}$, continental margin, back-arc, felsic caldera province with diverse $\mathrm{Zn}-\mathrm{Pb}-\mathrm{Ag}$ - (Cu-Au) sulfide and Fe-oxide deposits, Bergslagen region, Sweden. Econ. Geol. 1996. Vol. 91. P. 979-1008. doi: 10.2113/gsecongeo.91.6.979

Allen R., Stuart B., Ripa M., Jonsson R. Regional stratigraphy, basin evolution, and the setting of stratabound $\mathrm{Zn}-\mathrm{Pb}-\mathrm{Cu}-\mathrm{Ag}-\mathrm{Au}$ deposits in Bergslagen, Sweden. Final report for SGU-FoU project 03-1203/99, 2003. P. $1-80$.

Allen R., Ripa M., Jansson N. Palaeoproterozoic volcanic- and limestone-hosted $\mathrm{Zn}-\mathrm{Pb}-\mathrm{Ag}-(\mathrm{Cu}-\mathrm{Au})$ massive sulphide deposits and Fe oxide deposits in Bergslagen, Sweden. 33 IGC excursion. Excursion guide. 2008. No. 12. P. $14-20$.

Andersson U. B. The late Svecofennian, high-grade contact and regional metamorphism in southwestern Bergslagen (central southern Sweden). Final report 970519, 03-819/93. 1997. 36 p. doi: 10.13140/ 2.1.5088.5920

Andersson U. B. Age and P-T paths of metamorphism in the Bergslagen region, southern Sweden. Conf.: FoU-seminarium vid SGU. Uppsala, 2005 P. 22-24.

Andersson S., Jonsson E., HögdahlK. Genesis of $\mathrm{Pb}-\mathrm{Ag}-\mathrm{Cu}-\mathrm{Fe}-\mathrm{Zn}-(\mathrm{Au}-\mathrm{Sb}-\mathrm{As})$ mineralisation at Hornkullen, Bergslagen, Sweden: insights from ore mineralogy, textural relations and geothermoarometry. $31^{\text {st }}$ Nordic Geological Meeting. Lund, 2014.

Beunk F. F., Kuipers G. The Bergslagen ore province, Sweden: Review and update of an accreted orocline, 1.9-1.8 Ga BP. Precambrian Res. 2012. Vol. 216-219. P. 95-119. doi: 10.1016/j.precamres.2012.05.007

Bogdanova S., GorbachevR., Skridlaite G., Soesoo A., Taran L., Kurlovich D. Trans-Baltic Palaeoproterozoic correlations towards the reconstruction of supercontinent Columbia/Nuna. Precambrian Res. 2015. Vol. 259. P. 5-33. doi: 10.1016/j.precamres.2014.11.023

Dupuis C., Beaudoin G. Discriminant diagrams for iron oxide trace element fingerprinting of mineral deposit types. Miner. Deposita. 2011. Vol. 46, no. 4. P. 319-335. doi: 10.1007/s00126-011-0334-y

Erisalu E., Arvisto E. Report of the basement studies on Jõhvi magnetic anomaly and nearby. Geol. Survey of Estonia. EGF 3032 Tallinn, 1969. 257 p. (In Russian)

Hall A. J. Pyrite-pyrrhotine redox reactions in nature. Mineral. Mag. 1986. Vol. 50, no. 356. P. 223-229. doi: 10.1180/minmag. 1986.050.356.05

Jansson N. F. The origin of iron ores in Bergslagen, Sweden, and their relationships with polymetallic sulphide ores: PhD thesis. Luleå University of Technology, Sweden, 2011. 73 p.

Kähkönen $Y$. Svecofennian supracrustal rocks. Precambrian Geol. of Finland - Key to the Evolution of the Fennoscandian Shield. Eds. Lehtinen M., Nurmi P. A., Rämö O. T., Amsterdam: Elsevier, 2005. P. 343-406.

Lagoeiro L. E. Transformation of magnetite to hematite and its influence on the dissolution of iron oxide minerals. J. Metamorph. Petrol. 2004. Vol. 16, no. 3. P. 415-423. doi: 10.1111/j.1525-1314.1998.00144.x

Latvalahti U. Cu-Zn-Pb ores in the Aijala-Orijärvi area, southwestern Finland. Econ. Geol. 1979. Vol. 74, no. 5. P. $1035-1059$. doi: 10.2113 /gsecongeo.74.5.1035

Linari A. A. Report on diamond drilling near Jõhvi. Proceed. Tallinn Univ. Tech. 1940. Vol. 15. P. 1-27. (In Estonian)

MäkeläU. Geological and geochemical environments of Precambrian sulphide deposits in southwestern Finland. Annales Academiae Scientiarum Fennicae. 
Series A. III. Geologica-Geographica. 1989. Vol. 151. P. 1-102.

Nirgi S., Soesoo A. Precambrian iron-sulphide mineralization of NE Estonia. 21 ${ }^{\text {st }}$ EGU General Assembly, EGU2019. Geophysical Research Abstracts, 21. Vienna, 2019.

North American Geologic-Map Data Model Science Language Technical Team. Report on progress to develop a North American science-language standard for digital geologic-map databases; Appendix B - Classification of metamorphic and other composite-genesis rocks, including hydrothermally altered, impact-metamorphic, mylonitic, and cataclastic rocks, Version 1.0 (12/18/2004). Digital Mapping Techniques '04 - Workshop Proceed. / Ed. Soller D. R., U. S. Geological Survey Open-File Report. 2004. P. 1-56.

Petersell V. Geological and metallogeny features of the crystalline basement of the southern slope of the Baltic Shield. Tallinn: ENSV TA GI, 1976. P. 1-28. (In Russian)

Plado J., KiikK., Jokinen J., Soesoo A. Magnetic anomaly of the Jõhvi iron ore, northeastern Estonia, controlled by subvertical remanent magnetization. Est. J. Earth Sci. 2020. Vol. 69, no. 4. P. 189-199. doi: 10.3176/ earth.2020.13

Puura V., Kuuspalu T. Ore occurrences in crystalline basement of Uljaste and Jõhvi area. 1:500000. Map of metallogeny vol III. Geol. Survey of Estonia. Tallinn, 1966. EGF 2801. P. 1-267. (In Russian)

Puura V., Koppelmaa H. Exploration results of crystalline basement. Geol. Survey of Estonia. Tallinn, 1967. EGF 2982. (In Russian)

Puura V., Vaher R., Klein V., Koppelmaa H., Niin M., Vanamb V., Kirs J. Crystalline basement of Estonia. Moscow: Nauka, 1983. P. 1-208. (In Russian)

Puura V., Klein V., KikasR., Konsa M., Kuldkepp R., Soesoo A. Svecofennian metamorphic zones in the basement of Estonia: an overview. Proceed. Estonian Acad. Sci., Geol. 2004. Vol. 53, no. 3. P. 149-164.

Robertson S. Classification of metamorphic rocks. BGS Rock Classification Scheme. British Geological Survey Research Report, RR 99-02. 1999. Vol. 2. P. 1-24

Rytuba J. J. Arsenic minerals as indicators of conditions of gold deposition in Carlin-type gold deposits. J. Geochem. Explor. 1984. Vol. 25, no. 1-2. P. 237-238.

Slotznick S. P., Eiler J. M., Fischer W. W. The effects of metamorphism on iron mineralogy and the iron speciation redox proxy. Geochim. Cosmochim. Acta. 2018. Vol. 224. P. 96-115. doi: 10.1016/j.gca.2017.12.003

Sjöström H., Bergman S. Svecofennian metamorphic and tectonic evolution of east central Sweden: Research report of a project entitled: Svekofennisk meta- morf och tektonisk utveckling i östra mellansverige. Uppsala: Uppsala University, 1998. P. 1-42.

Soesoo A., Puura V., Kirs J., Petersell V., Niin M., All $T$. Outlines of the Precambrian basement of Estonia. Proceed. Estonian Acad. Sci., Geol. 2004. Vol. 53. P. $149-164$

Soesoo A., Kosler J., KuldkeppR. Age and geochemical constraints for partial melting of granulites in Estonia. Mineral. Petrol. 2006. Vol. 86. P. 277-300. doi: $10.1007 / \mathrm{s} 00710-005-0110-8$

Soesoo A., Nirgi S., Plado J. The evolution of the Estonian Precambrian basement: geological, geophysical and geochronological constraints. Transactions of KarRC RAS. 2020. Vol. 2. P 18-33. doi: 10.17076/ geo1185

Soesoo A., Nirgi S., Urtson K., Voolma M. Geochemistry, mineral chemistry and pressure - temperature conditions of the Jõhvi magnetite quartzites and magnetite-rich gneisses, NE Estonia. Est. J. Earth Sci. 2021a. Vol. 70, no. 2. P. 71-93. doi: 10.3176/earth.2021.05

Soesoo A. Main Precambrian and Paleozoic mineral resources of Estonia. Aspects Min. Miner. Sci. 2021b. Vol. 6, no. 3. P. 729-732. doi: 10.31031/AMMS. 2021.06.000639

Stephens M. B., Ripa M., Lundström I., Persson L., Bergman T., Ahl M., Wahlgren C. H., Persson P. H., Wickström $L$. Synthesis of the bedrock geology in the Bergslagen region, Fennoscandian Shield, south-central Sweden. Uppsala: Geol. Survey of Sweden. 2009. P. 1-259.

Stålhös G. A tectonic model for the Svecokarelian folding in east central Sweden. Geologiska Föreningen i Stockholm Förhandlingar. 1981. Vol. 103, no. 1. P. 33-46. doi: 10.1080/11035898109455202

Tikhomirov S. N. Geology of the crystalline basement in Leningrad oblast and Baltics II Leningrad: VSEGEI, 1966. P. 1-24. (In Russian)

Vaganova Z., Kadyrova M. Precambrian crystalline rocks and iron-rich quartzites based on the data of deep drill holes in Jõhvi. Geol. Survey of Estonia. Tallinn, 1948. EGF 125. (In Russian)

Voolma M., Soesoo A., Hade S. Geochemistry and P-T conditions of magnetite quarzites from Jõhvi Zone, NE Estonia. Res. Terrae: Proceed. of the $5^{\text {th }}$ Annual Meeting of Nordic Mineralogical Network V Annual Meeting. Tallinn, 2010. Vol. 31. P. 34-38.

Weihed P., Arndt N., Billström C., Duchesne J. C., Eilu P., Martinsson O., Papunen H. Lahtinen R. Precambrian geodynamics and ore formation: the Fennoscandian Shield. Ore Geol. Rev. Vol. 27. P. 273-322. doi: 10.1016/J. OREGEOREV. 2005.07.008

Received September 29, 2021 


\section{СВЕДЕНИЯ ОБ АВТОРАХ:}

Нирги, Сиим

старший геолог

Геологическая служба Эстонии

Раквере, Эстония, 44314

аспирант

Отделение геологии Института экологии и наук о Земле

Тартуский университет

Тарту, Эстония, 50411

эл. почта: siim.nirgi@egt.ee

\section{Соэсоо, Алвар}

профессор

Институт геологии

Таллиннский технический университет

Таллинн, Эстония, 19086

Отделение геологии Института экологии и наук о Земле

Тартуский университет

Тарту, Эстония, 50411

эл. почта: alvar.soesoo@gmail.com

\section{CONTRIBUTORS:}

Nirgi, Siim

Geological Survey of Estonia

5 F. R. Kreutzwaldi, 44314 Rakvere, Estonia

Institute of Ecology and Earth Sciences, Department

of Geology, University of Tartu

14a Ravila, 50411 Tartu, Estonia

e-mail: siim.nirgi@egt.ee

Soesoo, Alvar

Institute of Geology Tallinn University of Technology

5 Ehitajate tee, 19086 Tallinn, Estonia

Institute of Ecology and Earth Sciences, Department of Geology, University of Tartu

14a Ravila, 50411 Tartu, Estonia

e-mail: alvar.soesoo@gmail.com 